\title{
Screening of organic solvents for bioprocesses using aqueous-organic two-phase systems
}

Rosinha Grundtvig, Inês P.; Heintz, Søren; Krühne, Ulrich; Gernaey, Krist V.; Adlercreutz, Patrick; Hayler, John D.; Wells, Andy S.; Woodley, John M.

\author{
Published in: \\ Biotechnology Advances
}

Link to article, DOI:

10.1016/j.biotechadv.2018.05.007

Publication date:

2018

Document Version

Peer reviewed version

Link back to DTU Orbit

Citation (APA):

Rosinha Grundtvig, I. P., Heintz, S., Krühne, U., Gernaey, K. V., Adlercreutz, P., Hayler, J. D., Wells, A. S., \& Woodley, J. M. (2018). Screening of organic solvents for bioprocesses using aqueous-organic two-phase systems. Biotechnology Advances, 36(7), 1801-1814. https://doi.org/10.1016/j.biotechadv.2018.05.007

\section{General rights}

Copyright and moral rights for the publications made accessible in the public portal are retained by the authors and/or other copyright owners and it is a condition of accessing publications that users recognise and abide by the legal requirements associated with these rights.

- Users may download and print one copy of any publication from the public portal for the purpose of private study or research.

- You may not further distribute the material or use it for any profit-making activity or commercial gain

- You may freely distribute the URL identifying the publication in the public portal 


\title{
Screening of organic solvents for bioprocesses using aqueous-organic two-phase systems
}

Inês P. Rosinha Grundtvig ${ }^{1}$, Søren Heintz ${ }^{1}$, Ulrich Krühne ${ }^{1}$, Krist V. Gernaey ${ }^{1}$, Patrick Adlercreutz ${ }^{2}$, John D. Hayler $^{3}$, Andy S. Wells ${ }^{4}$ and John M. Woodley ${ }^{1}$

${ }^{1}$ Center for Process and Systems Engineering (PROSYS), Department of Chemical and Biochemical Engineering, Technical University of Denmark (DTU), DK-2800 Kgs Lyngby, Denmark.

${ }^{2}$ Department of Biotechnology, Lund University, SE-22100 Lund, Sweden

${ }^{3}$ GlaxoSmithKline Medicines Research Centre, Gunnels Wood Road, Stevenage, Hertfordshire SG1 2NY, United Kingdom

${ }^{4}$ Charnwood Technical Consulting Ltd, Parklands, Northage Close, Quorn, Leicestershire LE12 8AT, United Kingdom

\section{Corresponding author:}

John M Woodley; *E-mail: jw@kt.dtu.dk

\begin{abstract}
The application of conventional organic solvents is essential in several steps of bioprocesses in order to achieve sufficient economic efficiency. The use of organic solvents is frequently used either to partly or fully replace water in the reaction medium or as a process aid for downstream separation.

Nowadays, manufacturers are increasingly requested to avoid and substitute solvents with hazardous potential. Therefore, the solvent selection must account for potential environmental hazards, health and safety problems, in addition to fulfilling the ideal characteristics for application in a process.

For the first time, criteria including Environment, Health and Safety (EHS), as well as the technical requirements for reaction and separation have been reviewed, collected and integrated in a single organic solvent screening strategy to be used as a guideline for narrowing down the list of solvents to test experimentally. Additionally, we have also included a solvent selection guide based on the methodology developed in the Innovative Medicines Initiative CHEM21 (IMI CHEM21) project and applied specifically to water-immiscible solvents commonly used in bioprocesses.
\end{abstract}

Keywords: Organic solvents screening, Bioprocesses, Biphasic systems, Downstream processing, In situ product removal

\section{Introduction}

There is currently significant interest in the application of biotechnology to chemical manufacture, driven in part by the need to replace (or at least minimize) existing fossil feedstocks by renewable and sustainable ones. Likewise the chemical industry, and perhaps even more importantly the pharmaceutical industry, needs to use ever cleaner processes, with reduced reagent use and waste generation. For example, while the $E$ factor is a measure of the amount of waste produced in a 
process $(E$ factor $=\mathrm{kg}$ waste $/ \mathrm{kg}$ product $)($ Sheldon, 2017), it is perhaps more useful to examine the composition of the waste from a given process. This quickly motivates the need to reduce or replace the use of organic solvents, applied primarily for product recovery and purification. For this reason several pharmaceutical companies, academic groups and organisations like the ACS Green Chemistry Institute (GCI) Pharmaceutical Roundtable have successfully driven an agenda of solvent reduction and replacement (Constable et al., 2007; Jessop et al., 2015; Tucker and Faul, 2016). To a large extent this has been focused on chemical synthetic strategies. However, while this serves as a very valuable guidance for today, the range of industrial processes is changing. For example, already today several hundred small-molecule pharmaceutical production processes use one or more bioprocess steps (Buchholz et al., 2012; Meyer et al., 2013; Woodley, 2017). Indeed as industrial interest in cleaner synthesis grows it becomes clear that in the future many more bioprocesses will be implemented in industry (Cue and Zhang, 2009; Sheldon and Woodley, 2017). Even if fermentation and biocatalysis were to replace a significant fraction of the synthetic reactions in the fine chemical and pharmaceutical industry, it remains the case that the products still need to be recovered and purified. The downstream separation can include many potential unit operations which are dependent upon the product (as well as by-product and substrate) properties.

Nevertheless, for most biocatalytic reactions and fermentations the product is often toxic (leading to an irreversible loss of activity) or inhibitory (leading to a reversible loss of activity) to the biocatalyst/microorganism at concentrations much lower than are the minimum required to feed a conventional downstream process. This has been the major motivation behind the implementation of in situ product removal (ISPR), where inhibitory or toxic products are removed during the reaction (either at the site of the reaction, or else in a recycle loop) (Van Hecke et al., 2014; Woodley et al., 2008; Zou, 2014). Various methods have been proposed including the use of adsorption, pervaporation, perstraction, and crystallization. Extensive reviews have been written on this topic and a number of industrial processes use the technology (Carstensen et al., 2012; Dafoe and Daugulis, 2014; Freeman et al., 1993; Lye and Woodley, 1999; Stark and von Stockar, 2003; Van Hecke et al., 2014; Woodley et al., 2008). Of particular interest is that polymers have been used in many ISPR solutions (Phillips et al., 2013) and can potentially be an effective, safer and cheaper alternative to the use of organic solvents (Dafoe and Daugulis, 2014). Regardless of the type of phase used to recover product it is clear that systematic selection methods are required. On this premise we recognized that one of the most used separation methods (aqueous-organic liquidliquid extraction) could in particular benefit from a more systematic screening procedure for the organic solvent. In this review, for the first time, the criteria to screen for solvents for a bioprocess are integrated in a single report, accounting for both the technical, as well as EHS requirements which as we have indicated earlier are a prerequisite for industrial implementation. The collection of these criteria forms the basis of a screening procedure in particular focused on biphasic systems in bioprocesses in order to narrow down the number of solvents to be tested experimentally. In this paper in contrast to previous publications (Elgue et al., 2006; Gani, 2006; Zhou et al., 2014), we deliberately restrict ourselves to bioprocesses using enzymes or microorganisms, to manufacture chemical products. We consider this screening procedure essential for the scientific community involved in the early stage development and research of new bioprocesses. Interestingly, this rationale is supported by journals such as ChemSusChem (Kemeling, 2012) which has specifically asked authors to justify their choice of solvents in submitted manuscripts and if possible to consider replacing harmful ones.

\section{Use of organic solvents in bioprocesses}

Whilst the use of water-miscible organic solvents (e.g. ethanol, dimethyl sulfoxide) to help solubilize poorly-water soluble organic compounds in single phase biocatalytic systems has been 
widely reported in the scientific literature, such systems may give only a $10-20 \%$ increase in substrate and/or product concentration (Sheldon and Pereira, 2017). Additionally, with only a few exceptions, such polar solvents strip essential water from the biocatalyst resulting in a loss of enzyme stability (Gorman and Dordick, 1992; Kamal et al., 2013; Taher and Al-Zuhair, 2017; Yang et al., 2004). On the other hand, essentially water-immiscible organic solvents (containing only small amounts of water, at concentrations less than saturation) like n-hexane, t-butyl methyl ether etc. can be used for lipase reactions run in a synthetic direction (to avoid hydrolysis)(Bose and Keharia, 2013; Carvalho et al., 2015; Devi et al., 2017). In this paper we will focus on the third case, where water-immiscible solvents are used in a distinct phase from the aqueous phase, to form a two-liquid phase system.

Here the organic solvents are used for substrate supply, or product removal, in order to overcome the low water-solubility of organic compounds and enzyme inhibition by substrate or product. Potentially, the solvent may also be used to overcome an unfavourable equilibrium, although this requires sufficient driving force to be effective. In this way, the application of two-liquid phase systems improves the bioreaction space-time yield (productivity) as well as the product concentration fed to the downstream process, and in some cases the selectivity (Boghigian et al., 2011; Dafoe and Daugulis, 2014; Jung et al., 2013; Mutti and Kroutil, 2012).

\subsection{Bioreaction systems}

Several considerations are important in aqueous-organic two-phase biocatalytic systems. The organic phase may be deleterious to the biocatalyst in two ways; either by the presence of the interface (Martínez-Aragón et al., 2009; Perez-Rodriguez et al., 2003) or by the amount of organic solvent dissolved in the aqueous phase which may cause biocatalyst inactivation (Bes et al., 1995; Stepankova et al., 2013). Both appear to be important, but in many cases the biocatalyst needs to be kept away from the interface.

Despite the downside described above the introduction of an organic solvent in the bioreaction system presents several advantages such as the dissolution of substrates and products at higher concentrations in the reactor than would otherwise be achievable. This means that the downstream process can be fed at high concentrations, while avoiding inhibitory concentrations of substrate or product in the aqueous reaction environment (Hua and $\mathrm{Xu}, 2011$; Lima-Ramos et al., 2014). Easier product recovery may also result from the fact that the solvent has a low boiling point, facilitating evaporation (Dafoe and Daugulis, 2014). Likewise when designing an in-situ product removal (ISPR) process, the mode of contact (direct or indirect) between the biocatalyst and the organic phase which removes the product, should be considered (Stark and von Stockar, 2003; Woodley et al., 2008). A bioreaction system with direct solvent contact can be characterized by the direct exposure of the biocatalyst/cells to the organic solvent [Figure 1 a) and b)]. For a bioreaction system with indirect solvent contact [Figure $1 \mathrm{c}$ ) and d)] the biocatalyst is not in contact with the organic solvent (Stark and von Stockar, 2003; Woodley et al., 2008).

In Figure 1, two possibilities for running systems with direct contact are presented: a) corresponds to the exposure of the biocatalyst to organic solvent within the reactor and $b$ ) corresponds to the direct contact in a different vessel to the reactor through an external loop. Configuration a) has the advantage that both reaction and product removal take place in the same vessel and therefore the equipment costs are lower. Configuration $b$ ) reduces the contact time between the biocatalyst and the organic solvent by introducing an external loop through a separation unit. However, the choice 


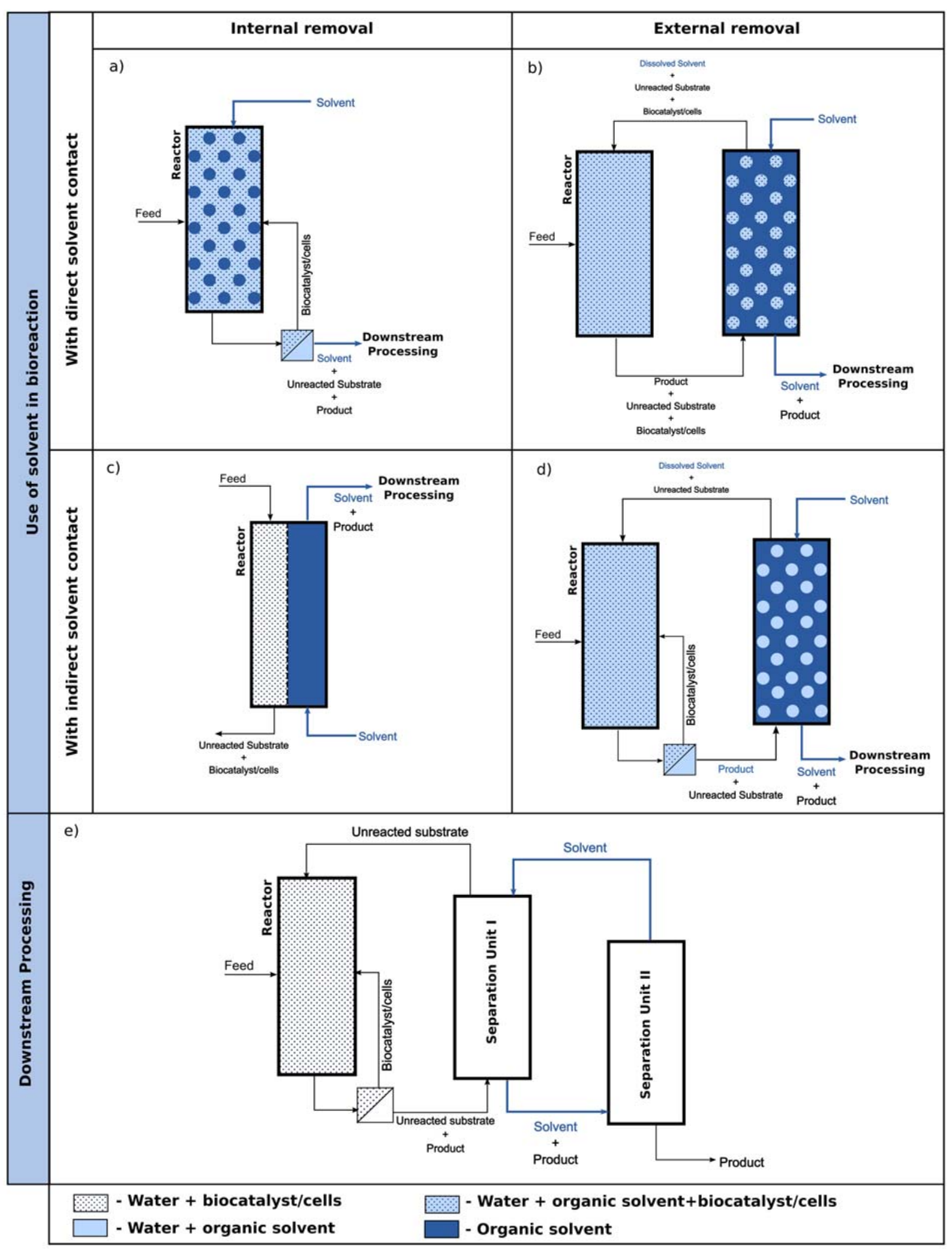

Figure 1 - Three process configurations for a bioreaction in an aqueous-organic two-phase system. Figure adapted from Stark and von Stockar, 2003. 
of solvent has to ensure that the solvent does not deactivate the biocatalyst/microorganism and the product has a high enough affinity and solubility.

Additionally, two configurations for indirect contact are presented in Figure 1: c) corresponds to a biphasic reactor with a membrane which separates the two liquid phases and d) corresponds to the separation of the biocatalyst/cells from the reactor medium and use of another vessel for the product removal. In systems such as c) there is usually a physical barrier such as a membrane which prevents the contact of the biocatalyst with the solvent (Stark and von Stockar, 2003; Woodley et al., 2008). In the configuration d), the biocatalyst/microorganism is never in direct contact with the solvent. The biocatalyst/microorganism is separated from the product and is recycled to the reactor. The medium with product dissolved, in its turn, enters a liquid-liquid extraction unit where the product is partitioned to the organic solvent and the medium that exits the vessel is recycled to the reactor.

The choice of solvent for a two liquid-phase system with direct contact is more difficult than for an indirect contact configuration since it must be compatible with the biocatalyst/microorganism and therefore requires a careful study of its toxic effects.

\subsection{Downstream processing}

Organic solvents play an important role as separation and purification agents for small-molecule chemical products from bioprocesses since they allow easy recovery of organic compounds. The use of water as a solvent may present some challenges for downstream processing such as separation difficulties, and its high specific heat capacity implies high energy consumption in distillation and difficulties rapidly heating and cooling (Adams et al., 2003). Moreover, the solubility of many of the most interesting compounds is often very low in water which implies excessive amounts of water in order to recover small amounts of product, resulting in high costs. When choosing an organic solvent, it should be possible to separate it from the aqueous phase as well as recover the desired products from the solvent as shown in Figure $1 \mathrm{e})(\mathrm{Gu}, 2000$; Koch, 2015). This should also enable options for recycling the solvent if viable, which could help optimize the economic feasibility of a given process, due to lower overall solvent use. Nowadays, the recycling of solvents is a common practice in industry. Besides the advantages mentioned above, the separation costs for isolating a product from an organic solvent can be much lower when compared to an aqueous system.

The determination of the exact downstream processing conditions depends not only on the nature of the product (solid or liquid) but also on the phase in which the product is primarily soluble. For a two-liquid phase system (i.e. with two immiscible phases), the operation unit mostly used to purify products is liquid-liquid extraction. Concerning energy consumption, liquid-liquid extraction can be more attractive since it is a less energy consuming process compared to distillation and gives a relatively high efficiency for product recovery (Kurzrock and Weuster-Botz, 2010; Stratakos and Koidis, 2016).

\section{Overview of criteria to screen solvents for an industrial bioprocess}

The list of solvents applicable to industrial processes is extensive and thus, the choice of the optimum solvent can be a significant challenge. Hence, at an early stage of process development, it is necessary to make a screening of solvents for evaluation of their suitability for the industrial process.

Figure 2 shows a screening procedure which is divided in four evaluation categories: (1) environment, health and safety, (2) affinity, recovery and recyclability properties, (3) stability and (4) 


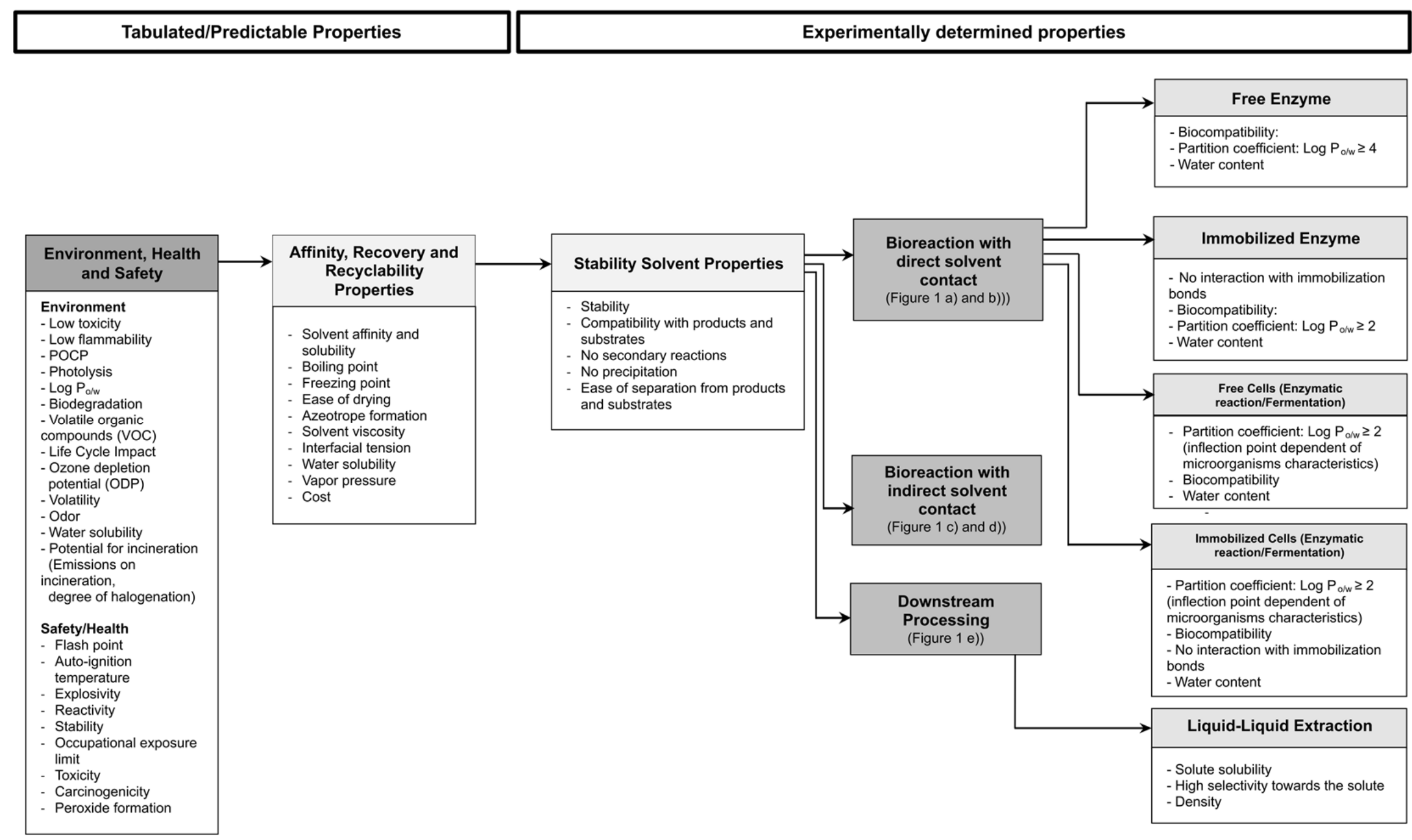

Figure 2 - Overview of criteria for choosing an organic solvent for a bioprocess divided in tabulated properties in scientific literature and experimentally determined properties which are dependent on system and compounds characteristics. 
application. The screening is also divided between tabulated properties which are already available in the literature and experimentally determined properties, which are dependent on the characteristics of the system and have to be experimentally investigated in order to evaluate the its performance.

The purpose of the screening procedure is to help narrowing the list of possible solvents to be applied in a bioprocess by evaluating the most important criteria first and eliminating those solvents which do not fulfill the requirements. The methodology starts by evaluating solvents in terms of environment, health and safety issues because this is the greatest concern for process development. Indeed, in order to implement a process it is necessary to fulfill legal and regulatory requirements in this category. Subsequently, solvents are evaluated in terms of recovery and recyclability properties and finally the list is shortened by considering those which fulfill the criteria for application in a given bioprocess.

Ultimately an experimental investigation has to be performed since the solvent is selected according to the specific system under study. Nevertheless, some of the listed properties such as $\log \mathrm{P}_{\mathrm{o} / \mathrm{w}}$ provide a direction for the search.

\subsection{Criteria to screen for organic solvents with low hazard environmental, health and safety (EHS)}

\section{issues}

The adequate selection of solvents is dependent on their suitability for a given application. However, considerations regarding solvent recovery, solvent release as well as safety at an industrial site have particular importance. Hence, the primary category to assess is their impact on environmental, safety and health. It is necessary to take several parameters into account such as those quantifying the environmental impact (ecotoxicity, flammability, ozone depletion, incineration potential, etc). Regarding health and safety, some of the parameters are: toxicity \& occupational exposure, auto-ignition temperature, boiling point, flash point, explosivity, reactivity and vapor pressure; these are particularly important considerations where a bioprocess is run in the presence of air or oxygen. Solvent selection guides are available, and some institutions and companies have also made studies to evaluate the hazards of the solvents and suggested alternative solvents which could substitute the most hazardous ones (Alfonsi et al., 2008; American Chemical Society (ACS), 2011; Elgue et al., 2006; Henderson et al., 2011; Prat et al., 2016, 2013).

\subsection{Criteria to evaluate the recovery strategies and affinity and stability of an organic solvent} When screening for organic solvents for a particular application in a process there are initially several considerations to take into account including the affinity, stability and recovery of the solvent.

The affinity of a given solvent towards a solute is a fundamental property to consider when choosing a solvent since it determines the viability of the solvent application. Even though this property is very specific for the process, it is possible to find data bases with information for specific solute-extractant pairs such as,(Dortmund Data Bank, 2018). In those cases where the information is not tabulated, the ternary phase behavior can be predicted using thermodynamic methods such as NRTL, UNIFAC and UNIFAQ. The successful application of these predictable methods has been widely reported in scientific literature (Abildskov et al., 2001; Brennan et al., 2012; Bruce and Daugulis, 1991; Cheng and Wang, 2010, 2007; Domańska et al., 2015; Ellegaard et al., 2009; Janseen et al., 1993; Malinowski, 2001, 1999; Malinowski and Daugulis, 1994; Modarresi et al., 2008; Priebe and Daugulis, 2018; Scilipoti et al., 2014). The reader should also note that any solvent selected in this way will still need be experimentally tested, not only for affinity but also for emulsion formation and biocompatibility. 
When choosing a solvent for a bioprocess it is also necessary to take into consideration parameters such as viscosity, vapor pressure and melting point (Martínez-Aragón et al., 2009; Tzia and Liadakis, 2003). The values of all these parameters should be low enough to ensure ease of handling and storage. For example, highly viscous solvents lead to problems effective liquid-liquid mass transfer. With respect to recovery and recyclability, the boiling point is an important parameter to consider, especially if the separation is done by distillation (Barwick, 1997). There are several other criteria to take into consideration as well, such as the ease of drying and azeotrope formation (Smallwood, 1996; Tzia and Liadakis, 2003). It is relevant to consider that all the factors mentioned above are very important in order to run a process with a solvent and solvent selection can be a delicate balance between the different parameters. The properties above are already tabulated and can be used for screening solvents and reduce the number of solvents to be tested.

The non-precipitation, non-reactivity and chemical stability in the reaction system of the solvent are also important factors to consider (Tzia and Liadakis, 2003). Likewise the solvent should be stable and not interact with the reaction solutes (e.g. substrate(s) and product(s)) and cause secondary reactions. Needless to say, being able to operate the process safely is of paramount importance. Since most of these properties are dependent on the characteristics of an individual system, experimental work is necessary in order to assess the suitability of the solvent for the process. Therefore, these criteria should be evaluated in the end of the screening process to a very short list of solvents already chosen considering the tabulated properties.

\subsection{Criteria for screening organic solvents as part of a reaction medium in two-liquid phase systems} with free or immobilized biocatalyst/microorganisms

There are some specific challenges related to the use of solvents in bioreactions. As mentioned earlier, solvents can be damaging to the biocatalyst, causing degradation and inactivation. For an enzymatic reaction in a two-liquid phase system, there are some basic principles that can be followed in order to shorten the list of feasible solvent candidates for initial testing. The solvent should be as apolar as possible. Nevertheless, it should be noted that for such systems the aqueousorganic interface can also have toxic effects on the biocatalyst. The $\log \mathrm{P}_{\mathrm{o} / \mathrm{w}}$ value is the accepted parameter for defining the polarity of a solvent. Hence, $\log \mathrm{P}_{\mathrm{o} / \mathrm{w}}$ is useful for describing the influence of a solvent on enzyme activity. In the scientific literature, high partition coefficients (Log $\mathrm{P}_{\mathrm{o} / \mathrm{w}}>4$ ) are considered suitable, whilst those with lower values have frequently been found toxic to biocatalysts (Halling, 1994; Laane et al., 1987; Straathof, 2003).

Solvents with $\log \mathrm{P}_{\mathrm{o} / \mathrm{w}}$ values higher than 4 present a low solubility in water and, practically, the enzyme dissolved in the aqueous phase does not have contact with the solvent and is able to support effective product synthesis. On the other hand polar solvents with $\operatorname{low} \log \mathrm{P}_{\mathrm{o} / \mathrm{w}}$ values $\left(\log \mathrm{P}_{\mathrm{o} / \mathrm{w}}<2\right)$ are more soluble in water and consequently remove the essential water from the enzyme and disrupt its conformation with attendant deactivation (Soo et al., 2003). Several authors have reported the effect of solvents on the performance of enzymes and have shown that enzymes present better activity in media containing solvents with high $\log \mathrm{P}_{\mathrm{o} / \mathrm{w}}$ values (Bemquerer et al., 1994; Koutinas et al., 2018; Lara and Park, 2004; Valivety et al., 1991; Zaks and Klibanov, 1985).

Interestingly, whilst the partition coefficient $\left(\log \mathrm{P}_{\mathrm{o} / \mathrm{w}}\right)$ is an important parameter to assess the suitability for an organic solvent for soluble enzymes, it has also been found useful for immobilized enzyme systems, although with a more relaxed requirements. For example it has been possible to achieve good enzyme performance in biphasic systems using immiscible organic solvents with lower Log $\mathrm{P}_{\mathrm{o} / \mathrm{w}}$ values (range 1-3) (Chaplin et al., 2001; Reslow et al., 1987). This indicates that the immobilization of the enzyme results in a shift of the $\log \mathrm{P}_{\mathrm{o} / \mathrm{w}}$-activity curve as shown in Figure 3 (Laane et al., 1986; Mionetto et al., 1994).Consequently, with immobilized 


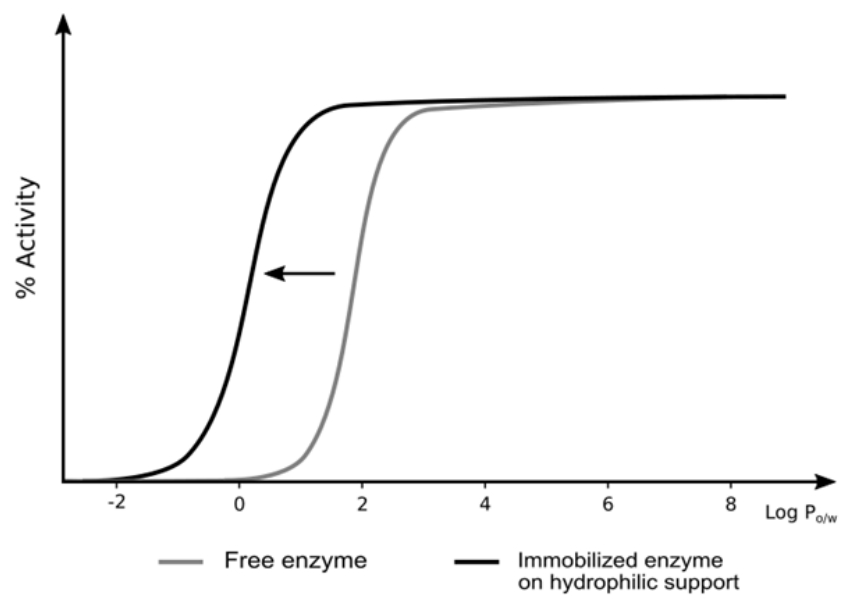

Figure 3-Schematic representation of enzymatic activity for both free enzyme and immobilized enzyme on a hydrophilic support plotted against $\log \mathrm{P}_{\mathrm{o} / \mathrm{w}}$ of the solvent. Figure adapted from Mionetto et al. 1994.

enzymes there is a broadening of the solvent polarity range and an increased number of suitable solvent options. In these reaction systems, it is believed that the support retains the water molecules and therefore stabilizes a water layer around the enzyme molecules. The water layer protects the enzyme molecules and therefore makes them more stable even in organic solvents with lower partition coefficients.

From the different studies reported, we can conclude that $\log \mathrm{P}_{\mathrm{o} / \mathrm{w}}$ should only be used as a guideline for screening biocatalyst-compatible solvents. In fact, it is not possible to determine the suitability of the solvent without performing experiments. Some exceptions to the guideline have been reported (Cantarella et al., 1993; Geok et al., 2003; Gonçalves et al., 1997).

Furthermore, the characterization of enzyme performance in organic media has often been reported in an inconsistent manner. So while some authors report the enzyme activity (Mionetto et al., 1994), or specific activity (Norin et al., 1988), other report the residual activity (Geok et al., 2003; Reslow et al., 1987) and others again, the reaction conversion or yield (Chaplin et al., 2001; Koutinas et al., 2018; Lara and Park, 2004). These inconsistencies mean that drawing conclusions about the use of $\log \mathrm{P}_{\mathrm{o} / \mathrm{w}}$ as a parameter for solvent selection is difficult.

For whole-cell biocatalytic systems and fermentation, the relation between cellular activity of different microorganisms against $\log \mathrm{P}_{\mathrm{o} / \mathrm{w}}$ is also represented by a sigmoidal curve, similar to that for soluble enzyme (Laane et al., 1987). Several authors (Bassetti and Tramper, 1994; Cruz et al., 2001; Fragnelli et al., 2012; Neumann et al., 2005; Rojas et al., 2004; Silva et al., 2010) have studied the relationship between cellular activity and $\log \mathrm{P}_{\mathrm{o} / \mathrm{w}}$. From their results, unsurprisingly it is possible to conclude that the inflection points between toxic and non-toxic solvents vary significantly between different microorganisms. Bruce and Daugulis have proposed that the tolerance of the microorganism is dependent on the characteristics of the cellular membrane (L J Bruce and Daugulis, 1991). Whole-cells biocatalysis using organic media has been reviewed and the authors concluded that the inflection point of the sigmoidal curve is in general above the value $\log \mathrm{P}_{\mathrm{o} / \mathrm{w}} 2$ (Heipieper et al., 2007; León et al., 1998). Nonetheless, it is still necessary to perform experimental screening work for the microorganism of interest. Some authors have engineered the microorganisms, in order to improve microorganisms tolerance to solvents, and in this way have 
adapted a specific cell to have tolerance to a specific solvent (Mukhopadhyay, 2015; Volmer et al., 2014; Zhang et al., 2015).

Regarding bioreactions in water-organic solvent two-phase systems with immobilized enzymes or cells, the toxicity of the solvent to the biocatalyst/microorganism is a crucial factor to consider when screening for organic solvents. However, the interaction of the solvents with the immobilization matrix is also an important factor to take into consideration. Immobilization by adsorption is the simplest method and is characterized by reversible surface interactions between enzyme/cells and the support material. The interaction forces can be van der Waals forces, ionic and hydrogen bonding interactions. Since these forces are weak, desorption can occur in the presence of organic solvents (Brena et al., 2013; Dwevedi, 2016). Synthetic polymer resins can be prone to swell with certain classes of solvent. On the other hand, porous silica and porous glass have been shown to be durable and resistant to solvent destruction (Datta et al., 2013). Entrapment, encapsulation and cross-linking are more resistant methods to solvent interactions. In fact, it has been reported that these methods are often used to retain catalytic activity in harsh conditions (temperature and $\mathrm{pH}$ extremes and exposure to organic solvents) (Kourkoutas et al., 2004).

\subsection{Criteria for screening organic solvents as extraction agents in downstream processes}

Crucial criteria to consider when choosing a solvent as an extraction agent are the solubility of the target compound to be extracted, affinity towards this compound and the ease of subsequent phase separation. For instance, when extracting the product with a solvent it is important that the product is highly soluble in the solvent in order to efficiently recover most of the product from the outlet stream of the reactor (Kolár et al., 2002). The ease of separation of the solvent from the aqueous phase is also important, since a complete separation reduces costs. Hence, a large density difference between the extract phase and raffinate phase (from which the components of interest have been removed) allows high capacities particularly in liquid-liquid extraction (Gu, 2000; Koch, 2015). Likewise, the higher the interfacial tension (Gu, 2000; Tzia and Liadakis, 2003), the more readily coalescence of emulsions will occur and the easier phase separation will be.

In some cases, the direct recovery of a product may not be possible using solvents alone and it is necessary to use a reactive liquid-liquid extraction which involves a reversible reaction between the desired chemical compound and the extractant or a host chemical species present in the extractant. Examples include the removal of carboxylic acids (acetic acid (Mahfud et al., 2008), lactic acid (Wasewar et al., 2003, 2002), pyruvic acid (Marti et al., 2011), citric acid (Poposka et al., 1998)) by amines. The extractions involve the complexation reaction of the undissociated acids and amines. The complexation reaction improves the distribution coefficient. The reaction promotes the migration of the product to the organic phase. The choice of the solvent is also important when establishing a reactive liquid-liquid extraction because it has to solvate the amine-acid complex to avoid its precipitation (Yang et al., 2007).

Another solution, in case direct extraction is not possible, is to manipulate other properties such as modifying the $\mathrm{pH}$ of the output aqueous solution can be useful for separation. An excellent example of this is the downstream processing for penicillin production. After filtration of the mycelium, the $\mathrm{pH}$ of the broth is adjusted to $\mathrm{pH} 2-2.5$ in order to convert penicillin acid carboxylate into penicillanic acid. The acidification of the broth increases the partition coefficient of penicillanic acid (Najafpour, 2007). However, penicillanic acid is unstable in aqueous solution, and this compound is recovered by an organic solvent, e.g. butyl acetate. The decision regarding the $\mathrm{pH}$ value to be selected should be a compromise between the partition coefficient and product stability (Wennersten, 2004) and acidification of the broth should be performed in order to minimize product degradation (Hook, 2006). 


\section{Solvent selection guide for biphasic bioreaction systems}

An overview of the criteria to take into account when selecting a solvent for a specific application in a process has been described in the preceding sections. In this section, a selection guide for solvents that are, or could potentially be, used in biphasic biocatalytic/fermentation reactions is described. The evaluation procedure used to rank the different solvents is similar to the CHEM21 solvent selection guide published by Prat et al. (Prat et al., 2016).

Although there are many beneficial uses for organic solvents in bioprocesses, the use of solvents presents several environmental, health and safety challenges. When choosing a solvent for the development of a process it is important to take into account the environmental impact of the chosen solvent, and the potential safety and health risks associated with handling and using the given solvent (Clark and Tavener, 2007). Solvents having significant issues should of course be avoided, if at all possible. There are several solvent selection guides in the scientific literature. GlaxoSmithKline (GSK) (Alder et al., 2016), the American Chemical Society, Green Chemistry Institute Pharmaceutical Roundtable (ACS GCIPR) (American Chemical Society (ACS), 2011) and the solvent guide from CHEM21 (Prat et al., 2016) have presented guides with numerical rankings and dividing solvents in categories. Pfizer's (Alfonsi et al., 2008) and Sanofi's (Prat et al., 2013) guides present the evaluation results solely in the form of a color code for each solvent, without a numerical ranking. In addition, the solvent guide from Pfizer presents an overall summarized evaluation for all solvents, rather than divided in categories.

The survey by Prat et al. (Prat et al., 2014) presents a summary and a comparison of the Health, Safety and Environment assessments of several solvent guides. The solvent guides considered were Astra Zeneca's, ACS GCIPR's, GSK's 2011 guide (Henderson et al., 2011), Pfizer's and Sanofi's. The main purpose of this survey was to compare the evaluation criteria across the different solvent guides and compare the consistency of solvent evaluation across the various guides. In the present article a new selection guide for solvents commonly used, or of potential use, as reaction media in biphasic biocatalysis is presented. Some of the included solvents have never been assessed in previous solvent selection guides due to their specific application in biocatalytic reaction systems. Other solvent selection guides focus strongly on solvents used in the main for synthetic organic chemistry applications (Alfonsi et al., 2008; American Chemical Society (ACS), 2011; Henderson et al., 2011; Prat et al., 2016, 2013). An accurate and detailed comparison of all of the required properties of solvents is not an easy or exact task, since the level and quality of data available for each solvent is different. This is especially true for the comparison of older solvents that might have a large amount of data available e.g. substances fully registered under REACH (ECHA 2016), and newer solvents where very little data is available (at least available in the public domain). A key feature of the CHEM21 methodology is that it allows a high level ranking of all solvents where basic physical/safety data and the Globally Harmonized System of Classification and Labeling of Chemicals (GHS) is known (Prat et al., 2016). The solvents in the guide presented here have been classified based on the methodology developed within the CHEM21 project. CHEM 21 is a collaborative project between European universities and companies and aims to develop sustainable biological and chemical alternatives to finite resources and more environmentally friendly processes. The guide presented here is targeted at process chemists and engineers charged with operating bioprocesses. In this guide we also provide some examples from the literature which document the use of the solvents in biocatalytic systems and additionally, the enzymes which have been used. Other useful data such as solubility in water, Log P and CAS number are also included. We hope these data will be useful for looking for greener solvents where similar Log P and/or water solubility values are needed for a successful bioprocess. For large scale processing, solvents which are solid close to ambient temperature can present specific logistical challenges, so solvents with 
$\mathrm{mp} \geq 10{ }^{\circ} \mathrm{C}$ have been marked in the table. The solvents included in the guide were chosen from a literature survey of biphasic bioreactions, or by looking for newer solvents that may have similar properties and could be good candidates for this type of transformation. Generally solvents have been chosen which have $10 \%$ or lower solubility in water as a cut off point for a water-immiscible organic solvent. In certain circumstances, solvents such as tetrahydrofuran and acetonitrile that are fully water-miscible can form biphasic mixtures with water (high aqueous solute content), but these were excluded. Data on water-miscible solvents can be found in other published guides (Alfonsi et al., 2008; American Chemical Society (ACS), 2011; Henderson et al., 2011; Prat et al., 2016, 2013). Solvents that are common to this guide and CHEM21 used the data collated for the CHEM21 guide (Prat et al., 2016). The data required to assess the new solvents were obtained from manufacturer's safety data/material safety data sheets - freely available from suppliers, and from the European Chemicals Agency, Registered Substances Data (ECHA-RS), 2016. In the case of the less common solvents and newer solvents, not all of the required data was available or found. In particular, it was difficult to find values for resistivity (the ability to accumulate a static charge). Under the methodology solvents likely to build up a static charge $\left(>10^{8} \Omega . \mathrm{m}\right)$ incrementally add 1 to the safety score. For the additional solvents here, ethers and hydrocarbons were scored as resistive, and the other solvents as non-resistive. Needless to say, before using any solvents at scale, a full assessment needs to be made of all operational and safety hazards, including resistivity. Where air is used for bio oxidation and/or for transformations with living cells, appropriate care needs to be taken to avoid the formation of an explosive head space if a flammable solvent is used. Since the processes under consideration here are all biphasic, the production of aqueous waste streams containing low levels of the organic solvent needs to be considered. Some calculated data on persistence, bioaccumulation and toxicity has been included in the table. Thus the solvent selection guide includes an evaluation of persistence in the environment, bioaccumulation in food chains and toxicity to fish. The persistence, bioaccumulation and toxicity (PBT) evaluation follows the criteria established by New Chemicals Program (EPA (U.S. Environmental Protection Agency), 2012). The persistence evaluation is performed by investigating the half-life of the compound in water and air. In relation to the water criteria, if the compound's half-life is less than 2 months it is considered recommended (green). If the compound's half-life is between 2 and 6 months it is considered problematic (amber). Solvents with a half-life greater than 6 months are considered hazardous (red). Persistence in air is also evaluated by the half-life; compounds with a half-life lower or equal to 2 days are considered harmless, those with a half-life greater than 2 days are considered hazardous (EPA (U.S. Environmental Protection Agency), 2012).

The bioaccumulation criterion corresponds to the bioconcentration factor of a chemical uptake from the surrounding media by an organism living in that media. If the range of bioconcentration factors is less than 1000, the solvent is considered recommended for industrial applications (green). Solvents with bioconcentration factors greater than or equal to 1000 and less than 5000 are considered to be problematic (amber). Solvents with bioconcentration factors higher than 5000 are considered hazardous and not advised to be applied in industrial applications (red) (EPA (U.S. Environmental Protection Agency), 2012).

Toxicity to fish is evaluated by the concentration of the solvent which is chronically toxic to fish, chronic toxicity value $(\mathrm{ChV})$. Solvents with a $\mathrm{ChV}$ greater than $10 \mathrm{mg} / \mathrm{L}$ and that do not present any toxic risk are considered harmless (green). $\mathrm{ChV}$ in the range of concentrations $0.1-10 \mathrm{mg} / \mathrm{L}$ present moderate concern and are considered problematic (amber). Solvents with ChV less than $0.1 \mathrm{mg} / \mathrm{L}$ are considered hazardous (red) (EPA (U.S. Environmental Protection Agency), 2012). Table 2 is the compilation of the assessment of the solvents which are commonly applied, or could be applied, in bioreactions as a medium. The guide contains a score for each parameter [1 (good) to 10 (bad)] and is color coded for easy reference. The guide is divided into safety, health and 
environmental sections, with an overall recommendation. Scoring is based on physical parameters such as boiling point, auto ignition temperature etc. and GHS statements. Full details of the methodology are given in the CHEM21 publication (Prat et al., 2016). For easy comparison in tabular form, the output is color coded. Green (recommended) indicates that the solvent can be used with few issues (given normal safe operating procedures are in place to deal with issues such as flammability, etc). Yellow (problematic) indicates that there may be some issues, but the solvent should be usable with appropriate mitigation strategies. Red - solvents labeled hazardous or highly hazardous should be replaced or avoided in developing new processes. In the overall ranking column, some solvents have a split ranking. This is due to current industrial thinking and practice that would generally move a solvent into a higher hazard band than that given by the ranking/scoring process.

For newer solvents that are not fully registered in REACH (thus potentially lacking in some data sets), the CHEM21 scoring methodology defaults to 5 (problematic/yellow). This is why solvents such as diethyl succinate and butyl butyrate rank as problematic when compared to very similar structures like ethyl, tert-butyl or isopropyl acetate, which are fully registered. When full datasets are available, these materials may become more harmonized in the guide. The REACH process is generating a lot of data on solvents and the overall picture is constantly changing. Looking into the future, before using any newer solvent, it would be advised to search for any new data or change in REACH status that could change the ranking in the table. It is worth noting that especially in the context of this guide, the methodology scores high boiling solvents (especially $>200^{\circ} \mathrm{C}$, e.g. diethyl succinate b.p. $=218^{\circ} \mathrm{C}$ ) poorly in the environmental section since these materials will be very energy intensive to purify or recover by distillation.

Lastly, the reader should note that the limits of the CHEM 21 selection algorithm define the assessment of each solvent. There are other solvent selection guides available in the literature and there are some differences in the classification of the solvents (Prat et al., 2014). Moreover, the assessment limits might also change with future legislation. In line with this, we are aware that some solvents which present some toxic and flammable properties (e.g. n-butanol) currently fall into the category of "Recommended" due to the limits of the evaluation. Moreover, azeotrope formation was not considered in the selection guide, although in principle it should also be taken into account when screening for solvents due to separation problems with the recovery of the solvent or waste water treatment. 


\begin{tabular}{|c|c|c|c|c|c|c|c|c|c|c|c|c|}
\hline \multicolumn{13}{|c|}{ High Level Solvent Guide for Biphasic Biocatalysed Reactions } \\
\hline \multirow{2}{*}{$\begin{array}{l}\text { Solvent, }\left(\text { CAS } \mathrm{N}^{\circ}\right) \\
\mathrm{mp} \text { if } \geq 10^{\circ} \mathrm{C}\end{array}$} & \multirow{2}{*}{$\begin{array}{c}\text { Solubility in } \\
\text { water } \\
\text { g litre }^{-1 *}\end{array}$} & \multirow{2}{*}{$\log P^{*}$} & \multirow{2}{*}{$\begin{array}{l}\text { Precedent for } \\
\text { use in biphasic } \\
\text { bioreaction }\end{array}$} & \multirow{2}{*}{ Reference } & \multirow{2}{*}{$\begin{array}{c}\text { In } \\
\text { published } \\
\text { guides }^{* *}\end{array}$} & \multirow{2}{*}{$\begin{array}{l}\text { Safety } \\
\text { Score }\end{array}$} & \multirow{2}{*}{$\begin{array}{l}\text { Health } \\
\text { Score }\end{array}$} & \multirow{2}{*}{$\begin{array}{l}\text { Environment } \\
\text { Score }\end{array}$} & \multicolumn{3}{|c|}{$\begin{array}{c}\text { PBT } \\
\text { profile }^{\star \star *}\end{array}$} & \multirow[t]{2}{*}{$\begin{array}{l}\text { Overall Ranking } \\
\text { using CHEM21 } \\
\text { methodology**** }\end{array}$} \\
\hline & & & & & & & & & $\mathbf{P}$ & B & $\mathbf{T}$ & \\
\hline \multicolumn{13}{|c|}{ Alcohols } \\
\hline $\begin{array}{l}\text { n-Butanol } \\
(71-36-3)\end{array}$ & 63.2 & 0.79 & Dehydrogenase & $\begin{array}{l}\text { (Cremonesi et } \\
\text { al., 1973) }\end{array}$ & $\begin{array}{l}\text { P, G, S, } \\
\text { C21, RT }\end{array}$ & 3 & 4 & 3 & & & & Recommended \\
\hline $\begin{array}{c}\text { Isobutanol } \\
(78-83-1)\end{array}$ & 70 & 0.79 & Oxidase & (Zaks, 1988) & $\begin{array}{c}\text { G, S, C21, } \\
\text { RT }\end{array}$ & 3 & 4 & 3 & & & & Recommended \\
\hline $\begin{array}{c}\text { n-Pentanol } \\
(71-41-0)\end{array}$ & 2.03 & 1.44 & Decarboxylase & $\begin{array}{c}\text { (Rosche et al., } \\
\text { 2004) }\end{array}$ & No & 3 & 2 & 3 & & & & Recommended \\
\hline $\begin{array}{c}\text { n-Heptanol } \\
(111-70-6)\end{array}$ & 1.63 & 2.2 & None found & & No & 1 & 2 & 5 & & & & Recommended \\
\hline $\begin{array}{c}\text { tert-Amyl alcohol } \\
(75-85-4)\end{array}$ & 98 & 0.77 & Oxidase & (Zaks, 1988) & $\mathbf{s}$ & 4 & 2 & 3 & & & & Recommended \\
\hline $\begin{array}{c}\text { Isoamyl alcohol } \\
(123-51-3)\end{array}$ & 21.2 & 1.35 & None found & & G, C21 & 3 & 2 & 3 & & & & Recommended \\
\hline $\begin{array}{l}\text { 1-Octanol } \\
(111-87-5)\end{array}$ & 0.5 & 3.15 & Oxygenase & $\begin{array}{c}\text { (Hüsken et al., } \\
\text { 2002) }\end{array}$ & No & 1 & 2 & 5 & & & & Recommended \\
\hline $\begin{array}{c}\text { Benzyl alcohol } \\
(100-51-6)\end{array}$ & 40 & 1.05 & None found & & $\begin{array}{c}\text { G, S, C21, } \\
\text { RT }\end{array}$ & 1 & 2 & 7 & & & & Problematic \\
\hline $\begin{array}{c}\text { 1-Dodecanol } \\
(112-53-8) \mathrm{mp} 22{ }^{\circ} \mathrm{C}\end{array}$ & 0.0019 & 5.13 & Reductase & $\begin{array}{l}\text { (De Wulf and } \\
\text { Thonart, 1989) }\end{array}$ & No & 1 & 5 & 7 & & & & Problematic \\
\hline $\begin{array}{l}\text { 1-Decanol } \\
(112-30-1)\end{array}$ & 0.021 & 4.5 & Dehydrogenase & $\begin{array}{l}\text { (Pinheiro and } \\
\text { Cabral, 1992) }\end{array}$ & No & 2 & 2 & 7 & & & & Problematic \\
\hline \multicolumn{13}{|c|}{ Esters } \\
\hline $\begin{array}{c}\text { Ethyl acetate } \\
(141-78-6)\end{array}$ & 87.9 & 0.68 & Dehydrogenase & $\begin{array}{c}\text { (Cremonesi et } \\
\text { al., 1973) }\end{array}$ & $\begin{array}{l}\mathrm{P}, \mathrm{G}, \mathrm{S} \\
\mathrm{C} 21, \mathrm{RT}\end{array}$ & 5 & 3 & 3 & & & & Recommended \\
\hline $\begin{array}{c}\text { tert-Butyl acetate } \\
(540-88-5)\end{array}$ & 6.7 & 1.64 & $\omega$-Transaminase & $\begin{array}{l}\text { (Meadows et } \\
\text { al., 2013) }\end{array}$ & G & 4 & 1 & 3 & & & & Recommended \\
\hline $\begin{array}{c}\text { n-Butyl acetate } \\
(123-86-4)\end{array}$ & 5.3 & 2.3 & KRED & $\begin{array}{c}\text { (Ye et al., } \\
\text { 2010) }\end{array}$ & $\begin{array}{c}\text { G, S, C21, } \\
\text { RT }\end{array}$ & 4 & 2 & 3 & & & & Recommended \\
\hline $\begin{array}{c}\text { Isobutyl acetate } \\
(110-19-0)\end{array}$ & 5.6 & 2.3 & None found & & $\mathrm{S}, \mathrm{C} 21, \mathrm{RT}$ & 4 & 2 & 3 & & & & Recommended \\
\hline
\end{tabular}




\begin{tabular}{|c|c|c|c|c|c|c|c|c|c|c|}
\hline $\begin{array}{c}\text { n-Propyl acetate } \\
(109-60-4)\end{array}$ & 18.7 & 1.27 & None found & & G & 4 & 2 & 3 & \multicolumn{2}{|c|}{ Recommended } \\
\hline $\begin{array}{c}\text { Isopropyl acetate } \\
(108-21-4)\end{array}$ & 31.9 & 1.03 & None found & & $\begin{array}{l}\mathbf{P}, \mathbf{G}, \mathbf{S} \\
\mathrm{C} 21, \mathrm{RT}\end{array}$ & 4 & 2 & 3 & \multicolumn{2}{|c|}{ Recommended } \\
\hline $\begin{array}{c}\text { Isoamyl acetate } \\
(123-92-2)\end{array}$ & 2 & 2.7 & None found & & $\mathrm{C} 21$ & 3 & 1 & 5 & \multicolumn{2}{|c|}{ Recommended } \\
\hline $\begin{array}{c}\text { n-Butyl butyrate } \\
(109-21-7)\end{array}$ & 0.31 & 2.83 & None found & & No & 3 & 5 & 5 & \multicolumn{2}{|c|}{ Problematic } \\
\hline $\begin{array}{c}\text { n-Octyl acetate } \\
(112-14-1)\end{array}$ & 0.033 & 3.81 & P450 & $\begin{array}{l}\text { (Toda et al., } \\
\text { 2012) }\end{array}$ & G & 1 & 5 & 7 & \multicolumn{2}{|c|}{ Problematic } \\
\hline $\begin{array}{c}\text { Diethyl succinate } \\
(123-25-1)\end{array}$ & 19 & 1.26 & None found & & G, S, C21 & 1 & 5 & 7 & \multicolumn{2}{|c|}{ Problematic } \\
\hline $\begin{array}{c}\text { Lauryl acetate } \\
(112-66-3)\end{array}$ & 0.00036 & 5.88 & P450 & $\begin{array}{c}\text { (Garikipati et } \\
\text { al., 2009) }\end{array}$ & No & 1 & 5 & 5 & \multicolumn{2}{|c|}{ Problematic } \\
\hline $\begin{array}{c}\text { Ethyl decanoate } \\
(106-33-2)\end{array}$ & 0.00041 & 5.71 & P450 & $\begin{array}{c}\text { (Tan and Day, } \\
1998)\end{array}$ & No & 1 & 5 & 7 & \multicolumn{2}{|c|}{ Problematic } \\
\hline $\begin{array}{c}\text { Ethyl oleate } \\
(111-62-6)\end{array}$ & $6 \times 10^{-7}$ & 8.51 & P450 & $\begin{array}{c}\text { (Kuhn et al., } \\
\text { 2012) }\end{array}$ & No & 1 & 5 & 7 & \multicolumn{2}{|c|}{ Problematic } \\
\hline $\begin{array}{c}\text { FAME-Fatty acid } \\
\text { methyl esters (67762- } \\
38-3)\end{array}$ & 0.000023 & $>6.2$ & P450 & $\begin{array}{l}\text { (Schrewe et } \\
\text { al., 2014) }\end{array}$ & No & \multicolumn{3}{|c|}{ Mixture } & \multicolumn{2}{|c|}{ Problematic } \\
\hline $\begin{array}{c}\text { Bis n-butyl phthalate } \\
(84-74-2)\end{array}$ & 0.011 & 4.46 & KRED & $\begin{array}{c}\text { (He et al.. } \\
2006)\end{array}$ & No & 1 & 9 & 7 & \multicolumn{2}{|c|}{ Hazardous } \\
\hline $\begin{array}{c}\text { bis(2-ethylhexyl) } \\
\text { phthalate }(117-81-7)\end{array}$ & $3 \times 10^{-6}$ & 7.86 & P450 & $\begin{array}{c}\text { (Park et al., } \\
\text { 2007) }\end{array}$ & No & 1 & 9 & 7 & \multicolumn{2}{|c|}{ Hazardous } \\
\hline $\begin{array}{c}\text { Tricaprylin } \\
(538-23-8) \\
\end{array}$ & $1.5 \times 10^{-8}$ & 9.2 & Plant cell culture & (Dutta, 1994) & No & 1 & 5 & 7 & \multicolumn{2}{|c|}{ Problematic } \\
\hline \multicolumn{11}{|c|}{ Ketones } \\
\hline $\begin{array}{c}\text { Methyl Isobutyl ketone } \\
(\text { MIBK) }(108-10-1)\end{array}$ & 14.1 & 1.9 & a-Galactosidase & $\begin{array}{c}\text { (Bennett et al., } \\
\text { 1992) }\end{array}$ & $\begin{array}{c}\text { S,G,C21, } \\
\text { RT }\end{array}$ & 4 & 2 & 3 & \multicolumn{2}{|c|}{ Recommended } \\
\hline $\begin{array}{c}\text { Cyclohexanone } \\
(108-94-1)\end{array}$ & 90 & 0.86 & Imidase & $\begin{array}{c}\text { (Ogawa et al., } \\
2000)\end{array}$ & $\begin{array}{c}\text { G, S, C21, } \\
\text { RT }\end{array}$ & 3 & 3 & 5 & $\mathbf{R}$ & $\mathbf{P}$ \\
\hline $\begin{array}{c}\text { 2-Octanone } \\
(111-13-7) \\
\end{array}$ & 0.9 & 2.5 & KRED & $\begin{array}{c}\text { (Kohlmann et } \\
\text { al., 2011) }\end{array}$ & No & 3 & 5 & 5 & \multicolumn{2}{|c|}{ Problematic } \\
\hline $\begin{array}{l}\text { 2-Undecanone } \\
(112-12-9) \mathrm{mp} 15^{\circ} \mathrm{C}\end{array}$ & 0.04 & 4.1 & Oxidation & $\begin{array}{c}\text { (Collins and } \\
\text { Daugulis, } \\
1997) \\
\end{array}$ & No & 1 & 5 & 7 & \multicolumn{2}{|c|}{ Problematic } \\
\hline \multicolumn{11}{|c|}{ Ethers } \\
\hline
\end{tabular}




\begin{tabular}{|c|c|c|c|c|c|c|c|c|c|c|}
\hline $\begin{array}{c}\text { Dimethyl ether }^{\top} \\
(115-10-6)\end{array}$ & 335 & 0.07 & KRED & $\begin{array}{l}\text { (Lu et al., } \\
2004)\end{array}$ & G & 9 & 2 & 7 & $\mathbf{H}$ & HH \\
\hline $\begin{array}{c}\text { Diethyl ether } \\
(60-29-7)\end{array}$ & 43.1 & 1.05 & Dehydrogenase & $\begin{array}{l}\text { (Cremonesi et } \\
\text { al., 1973) }\end{array}$ & $\begin{array}{l}\mathrm{P}, \mathrm{G}, \mathrm{S} \\
\mathrm{C} 21, \mathrm{RT}\end{array}$ & 10 & 3 & 7 & $\mathrm{H}$ & HH \\
\hline $\begin{array}{c}\text { Diisopropyl ether } \\
(108-20-3)\end{array}$ & 3.1 & 1.52 & $\begin{array}{l}\text { Enoate } \\
\text { reductase }\end{array}$ & $\begin{array}{l}\text { (Hall et al., } \\
\text { 2012) }\end{array}$ & $\begin{array}{l}\mathrm{P}, \mathrm{G}, \mathrm{S} \\
\mathrm{C} 21, \mathrm{RT}\end{array}$ & 9 & 3 & 5 & \multicolumn{2}{|c|}{ Hazardous } \\
\hline $\begin{array}{c}\text { Dibutyl ether } \\
(142-96-1)\end{array}$ & 0.11 & 3.35 & $\omega$-Transaminase & $\begin{array}{l}\text { (Meadows et } \\
\text { al., 2013) }\end{array}$ & $\mathbf{S}$ & 5 & 2 & 5 & \multicolumn{2}{|c|}{ Problematic } \\
\hline $\begin{array}{c}2- \\
\text { Methyltetrahydrofuran } \\
(96-47-9)\end{array}$ & 140 & 1.1 & $\begin{array}{l}\text { Benzaldehyde } \\
\text { lyase }\end{array}$ & $\begin{array}{l}\text { (Shanmuganat } \\
\text { han et al., } \\
\text { 2011) }\end{array}$ & $\begin{array}{l}\mathrm{P}, \mathrm{G}, \mathrm{S} \\
\mathrm{C} 21, \mathrm{RT}\end{array}$ & 6 & 3 & 3 & $\mathbf{R}$ & $\mathbf{P}$ \\
\hline $\begin{array}{c}\text { Cyclopentyl methyl } \\
\text { ether (CPME) (5614- } \\
37-9)\end{array}$ & 3.1 & 1.59 & $\begin{array}{l}\text { Benzaldehyde } \\
\text { lyase }\end{array}$ & $\begin{array}{l}\text { (Wiedner et } \\
\text { al., 2015) }\end{array}$ & $\begin{array}{c}\text { G, S, C21, } \\
\text { RT }\end{array}$ & 7 & 2 & 5 & \multicolumn{2}{|c|}{ Problematic } \\
\hline $\begin{array}{l}\text { tert-Butyl methyl ether } \\
\text { (TBME) (1634-04-4) }\end{array}$ & 41.9 & 1.23 & $\begin{array}{l}\text { Hydroxy nitrile } \\
\text { Lyase }\end{array}$ & $\begin{array}{l}\text { (Wiedner et } \\
\text { al., 2015) }\end{array}$ & $\begin{array}{l}\mathrm{P}, \mathrm{G}, \mathrm{S} \\
\mathrm{C} 21, \mathrm{RT}\end{array}$ & 8 & 3 & 5 & \multicolumn{2}{|c|}{ Hazardous } \\
\hline $\begin{array}{l}\text { Ethyl tert-butyl ether } \\
\text { (ETBE) (637-92-3) }\end{array}$ & 2.37 & 1.48 & None found & & G, S, C21 & 7 & 3 & 3 & \multicolumn{2}{|c|}{ Problematic } \\
\hline $\begin{array}{l}\text { tert-Amyl methyl ether } \\
\text { (TAME) (994-05-8) }\end{array}$ & 10.7 & 1.55 & None found & & G, C21 & 6 & 2 & 3 & \multicolumn{2}{|c|}{ Recommended } \\
\hline $\begin{array}{c}\text { Diisoamyl ether } \\
(544-01-4)\end{array}$ & 0.028 & 5.08 & Dehydrogenase & $\begin{array}{l}\text { (Hocknull and } \\
\text { Lilly, 1990) }\end{array}$ & No & 4 & 2 & 7 & \multicolumn{2}{|c|}{ Problematic } \\
\hline $\begin{array}{c}\text { Anisole } \\
(100-66-3)\end{array}$ & 1.71 & 2.11 & Lipase & (Wells, 2010) & $\begin{array}{c}\text { G, S, C21, } \\
\text { RT }\end{array}$ & 4 & 1 & 5 & $\mathbf{P}$ & $\mathbf{R}$ \\
\hline \multicolumn{11}{|c|}{ Halogenated } \\
\hline $\begin{array}{c}\text { Dichloromethane } \\
\text { (DCM) } \\
(75-09-2)\end{array}$ & 13.2 & 1.25 & Dehydrogenase & $\begin{array}{l}\text { (Cremonesi et } \\
\text { al., 1973) }\end{array}$ & $\begin{array}{l}\text { P, G, S, } \\
\text { C21, RT }\end{array}$ & 1 & 7 & 7 & \multicolumn{2}{|c|}{ Hazardous } \\
\hline $\begin{array}{c}\text { Chloroform } \\
(67-66-3)\end{array}$ & 8.7 & 1.97 & Protease & $\begin{array}{c}\text { (Ogino et al., } \\
\text { 1995) }\end{array}$ & $\begin{array}{l}\text { P, G, S, } \\
\text { C21, RT }\end{array}$ & 2 & 7 & 5 & $\mathbf{P}$ & HH \\
\hline $\begin{array}{c}\text { Carbon tetrachloride } \\
(56-23-5)\end{array}$ & 0.65 & 2.64 & Oxidase & $\begin{array}{c}\text { (Liu et al., } \\
\text { 1996) }\end{array}$ & $\begin{array}{l}\mathrm{P}, \mathrm{G}, \mathrm{S} \\
\mathrm{C} 21, \mathrm{RT}\end{array}$ & 2 & 7 & 10 & $\mathbf{H}$ & HH \\
\hline $\begin{array}{c}\text { 1,2-Dichloroethane } \\
(107-06-2)\end{array}$ & 7.9 & 1.45 & None found & & $\begin{array}{l}\mathrm{P}, \mathrm{G}, \mathrm{S} \\
\mathrm{C} 21, \mathrm{RT}\end{array}$ & 4 & 10 & 3 & H & HH \\
\hline $\begin{array}{c}\text { Chlorobenzene } \\
(108-90-7)\end{array}$ & 0.21 & 2.98 & Dehydrogenase & $\begin{array}{c}\text { (Cremonesi, } \\
\text { 1975) }\end{array}$ & $\begin{array}{c}\text { G, S, C21, } \\
\text { RT }\end{array}$ & 3 & 2 & 7 & \multicolumn{2}{|c|}{ Problematic } \\
\hline $\begin{array}{c}\text { Methoxyperfluorobutane } \\
(163702-07-6)\end{array}$ & 0.01 & 3.93 & Nitrile hydratase & $\begin{array}{l}\text { (Zhu et al., } \\
\text { 2015) }\end{array}$ & No & 3 & 6 & 5 & \multicolumn{2}{|c|}{ Problematic } \\
\hline Benzotrifluoride & 0.21 & 3.01 & None found & & G, RT & 5 & 5 & 7 & \multicolumn{2}{|c|}{ Problematic } \\
\hline
\end{tabular}




\begin{tabular}{|c|c|c|c|c|c|c|c|c|c|c|}
\hline$(98-08-8)$ & & & & & & & & & & \\
\hline \multicolumn{11}{|c|}{ Aromatic hydrocarbons } \\
\hline $\begin{array}{l}\text { Benzene } \\
(71-43-2)\end{array}$ & 1.78 & 2.1 & KRED & $\begin{array}{l}\text { (Shi et al., } \\
\text { 2008) }\end{array}$ & $\begin{array}{l}\mathrm{P}, \mathrm{G}, \mathrm{S} \\
\mathrm{C} 21, \mathrm{RT}\end{array}$ & 6 & 10 & 3 & $\mathbf{H}$ & HH \\
\hline $\begin{array}{l}\text { Toluene } \\
(108-88-3)\end{array}$ & 0.52 & 2.73 & Nitrile hydratase & $\begin{array}{l}\text { (Cull et al., } \\
\text { 2001) }\end{array}$ & $\begin{array}{c}\mathrm{P}, \mathrm{G}, \mathrm{S} \\
\mathrm{C} 21\end{array}$ & 5 & 6 & 3 & \multicolumn{2}{|c|}{ Problematic } \\
\hline $\begin{array}{c}\text { Xylene } \\
(1330-20-7)\end{array}$ & 0.16 & 3.15 & Oxidase & $\begin{array}{c}\text { (Aono et al., } \\
\text { 1994) }\end{array}$ & $\begin{array}{l}\text { P, G, S, } \\
\text { C21, RT }\end{array}$ & 4 & 2 & 5 & \multicolumn{2}{|c|}{ Problematic } \\
\hline $\begin{array}{l}\text { p-Cymene } \\
(99-87-6)\end{array}$ & 0.03 & 4.1 & Lipase & $\begin{array}{l}\text { (Paggiola et } \\
\text { al., 2014) }\end{array}$ & G, S, C21 & 4 & 5 & 5 & \multicolumn{2}{|c|}{ Problematic } \\
\hline $\begin{array}{c}\text { Tetralin } \\
(119-64-2) \\
\end{array}$ & 0.045 & 3.78 & Reductase & $\begin{array}{c}\text { (Ferrante et } \\
\text { al., 1995) }\end{array}$ & $\mathbf{S}$ & 3 & 6 & 7 & \multicolumn{2}{|c|}{ Problematic } \\
\hline $\begin{array}{l}\text { Cumene } \\
(98-82-8)\end{array}$ & 0.05 & 3.55 & None found & & S, G & 5 & 2 & 7 & \multicolumn{2}{|c|}{ Problematic } \\
\hline \multicolumn{11}{|c|}{ Aliphatic hydrocarbons } \\
\hline $\begin{array}{l}\text { n-Pentane } \\
(109-66-0)\end{array}$ & 0.039 & 3.45 & None found & & $\begin{array}{c}\mathrm{P}, \mathrm{G}, \mathrm{S} \\
\mathrm{C} 21\end{array}$ & 8 & 3 & 7 & \multicolumn{2}{|c|}{ Hazardous } \\
\hline $\begin{array}{l}\text { n-Hexane } \\
(110-54-3)\end{array}$ & 0.01 & 4 & KRED & $\begin{array}{c}\text { (de Gonzalo et } \\
\text { al., 2007) }\end{array}$ & $\begin{array}{l}\mathrm{P}, \mathrm{G}, \mathrm{S} \\
\mathrm{C} 21, \mathrm{RT}\end{array}$ & 8 & 7 & 7 & \multicolumn{2}{|c|}{ Hazardous } \\
\hline $\begin{array}{l}\text { n-Heptane } \\
(142-82-5)\end{array}$ & 0.0024 & 4.5 & Dehalogenase & (Zou, 2014) & $\begin{array}{l}\mathrm{P}, \mathrm{G}, \mathrm{S} \\
\mathrm{C} 21, \mathrm{RT}\end{array}$ & 6 & 2 & 7 & \multicolumn{2}{|c|}{ Problematic } \\
\hline $\begin{array}{c}\text { n-Octane } \\
(111-65-9)\end{array}$ & 0.0007 & 5.15 & Nitroreductase & $\begin{array}{c}\text { (Meyer et al., } \\
\text { 2006) }\end{array}$ & S, C21 & 5 & 2 & 7 & \multicolumn{2}{|c|}{ Problematic } \\
\hline $\begin{array}{l}\text { Isooctane } \\
(540-84-1)\end{array}$ & 0.0022 & 4.08 & Lipoxygenase & $\begin{array}{l}\text { (Kermasha et } \\
\text { al., 2002) }\end{array}$ & G, RT & 6 & 2 & 7 & \multicolumn{2}{|c|}{ Problematic } \\
\hline $\begin{array}{c}\text { Cyclohexane } \\
(110-82-7)\end{array}$ & 0.052 & 3.44 & Esterase & (Lee, 1997) & $\begin{array}{l}\mathrm{P}, \mathrm{G}, \mathrm{S} \\
\mathrm{C} 21, \mathrm{RT}\end{array}$ & 6 & 3 & 7 & \multicolumn{2}{|c|}{ Problematic } \\
\hline $\begin{array}{c}\text { Methylcyclohexane } \\
(108-87-2)\end{array}$ & 0.014 & 3.88 & None found & & $\begin{array}{l}\mathrm{P}, \mathrm{G}, \mathrm{S} \\
\mathrm{C} 21, \mathrm{RT}\end{array}$ & 6 & 2 & 7 & \multicolumn{2}{|c|}{ Problematic } \\
\hline $\begin{array}{c}\text { Petroleum ether 60/80 } \\
(101316-46-5) \\
\end{array}$ & As n-hexane & $\begin{array}{c}\text { As } n- \\
\text { hexane }\end{array}$ & KRED & $\begin{array}{c}\text { (Pathan et al., } \\
\text { 2012) } \\
\end{array}$ & G & \multicolumn{3}{|c|}{ Mixture } & $\mathbf{P}$ & H \\
\hline $\begin{array}{c}\text { Paraffin oil } \\
(8012-95-1)\end{array}$ & Insoluble & $>4$ & Oxidase & $\begin{array}{c}\text { (Oda et al., } \\
\text { 1996) }\end{array}$ & No & \multicolumn{3}{|c|}{ Mixture } & $\mathbf{P}$ & H \\
\hline $\begin{array}{c}\text { Decane } \\
(124-18-5)\end{array}$ & 0.000083 & 5.86 & Expandase & $\begin{array}{c}\text { (Gao and } \\
\text { Demain, 2001) }\end{array}$ & No & 4 & 2 & 5 & \multicolumn{2}{|c|}{ Problematic } \\
\hline $\begin{array}{l}\text { Dodecane } \\
(112-40-3)\end{array}$ & 0.000005 & 6.98 & KRED & $\begin{array}{l}\text { (Huang et al., } \\
\text { 2005) }\end{array}$ & No & 2 & 2 & 7 & \multicolumn{2}{|c|}{ Problematic } \\
\hline Tetradecane & $2.8 \times 10^{-1}$ & 7.2 & Dioxygenase & (Collins et al., & No & 2 & 2 & 7 & \multicolumn{2}{|c|}{ Problematic } \\
\hline
\end{tabular}




\begin{tabular}{|c|c|c|c|c|c|c|c|c|c|}
\hline (629-59-4) & & & & 1995) & & & & & \\
\hline $\begin{array}{c}\text { Hexadecane } \\
(544-76-3) \mathrm{mp} 18{ }^{\circ} \mathrm{C}\end{array}$ & 0.000001 & 8.20 & P450 & $\begin{array}{c}\text { (Furuhashi, } \\
1986)\end{array}$ & No & 2 & 2 & 7 & Problematic \\
\hline $\begin{array}{l}\text { D-Limonene } \\
(5989-27-5)\end{array}$ & 0.006 & 4.4 & Hydratase & $\begin{array}{l}\text { (Savithiry et } \\
\text { al., 1997) }\end{array}$ & S, C21 & 4 & 2 & 7 & Problematic \\
\hline $\begin{array}{c}\text { Turpentine } \\
(8006-64-2)\end{array}$ & 0.002 to 0.35 & 3 to 6 & None found & & S, C21 & 4 & 2 & 7 & Problematic \\
\hline
\end{tabular}

* Data from ECHA database [(ECHA-RS), 2016], literature values (sourced from the Reaxys database, Chemspider) or calculated. Values between 20 and $30{ }^{\circ} \mathrm{C}$.

** Solvent listed in other guides P=Pfizer (Alfonsi et al., 2008), G= GSK (Alder et al., 2016), S= Sanofi (Prat et al., 2013), C21= CHEM21 (Prat et al., 2016), RT= ACS GCI Pharmaceutical Roundtable (ACS 2011).

Grey shading indicates scoring is not appropriate due to mixtures, or values cannot be calculated for PBT profiler (Environmental Health Analysis Center, 2012)

*** Calculated environmental fate http://www.pbtprofiler.net/

$\mathrm{P}=$ Persistence

$\mathrm{B}=$ Bioaccumulation

$\mathrm{T}=$ Toxicity to fish

**** Recommendation as an output from the CHEM21 solvent selection methodology (Prat et al., 2016). Where a cell is split, the first column represents the output from the tool. However, for certain solvents, a second column has been added to reflect current industrial practice and thinking.

$\dagger$ solvent used under pressure, the boiling point of dimethyl ether $-24{ }^{\circ} \mathrm{C}$ at atmospheric pressure. 


\section{Concluding remarks and future perspectives}

This article summarizes water-immiscible solvent applications in bioprocesses and enumerates the different criteria to take into account in order to select a solvent. The criteria have been compiled and organized in a screening procedure which helps to narrow down the number of potentially feasible solvents to be tested experimentally during early stage process development, and to help guide chemists and engineers towards solvents with the best EHS profiles. The most important properties that are necessary to consider when screening organic solvents for a process are related to their environment, health and safety impact, recoverability and stability and their application in the process, as a reaction medium or applied to downstream processing.

Unfortunately, an ideal solvent is not always available from the shortlist of solvent options, and it is not always possible to fulfill all of the requirements. For example solvents with high Log P values are favored for two-liquid phase systems with free, immobilized biocatalysts or whole cells, whereas these are the very solvents which tend to persist in the environment and score poorly in the environmental assessment of the solvent guide. More lipophilic solvents also tend to have higher resistivity and consequently a higher safety score. Therefore, when making the final choice it is necessary to take a decision about the importance of the evaluation categories and to set strategies to overcome the constraints of the unfulfilled requirements. These strategies should still establish a safe and environmentally friendly process with reasonable acceptable costs.

Moreover, sometimes there are also process challenges to overcome such as deactivation of the biocatalyst in the presence of an organic solvent. This can often be overcome by using an indirect solvent contact process. In fact, it is also possible to avoid the contact of the biocatalyst with the solvent by making the extraction outside of the reactor without recirculation of the aqueous phase to the reactor - Figure 1 .

The selection of solvents for application in industrial processes has been changing over the past two decades. In fact, today there is a tendency both in industry and in research to choose a solvent taking greater consideration of the environmental impact and also an impact on health, safety and costs aspects. As an example GlaxoSmithKline Pharmaceuticals' most frequently used solvents list has changed towards greener solvents. Solvents such as toluene, dichloromethane and tetrahydrofuran, which were applied greatly in industry in the 90's, are presently being replaced. The three top ranked solvents for industrial application were 2-propanol, ethyl acetate and methanol. The list of the 10 top ranked solvents includes also ethanol, n-heptane, tetrahydrofuran, toluene, dichloromethane, acetic acid and acetonitrile (Constable et al., 2007). Moreover, a survey of solvent usage in development of processes revealed that although there is some room for improvement on substituting solvents of concern, there is already some reduction of chloroform and n-hexane applications. Additionally, this investigation shows that the usage of dipolar aprotic solvents at larger scale ( $>100 \mathrm{~kg}$ scale) is much smaller than in processes at smaller scale (Ashcroft et al., 2015). Another factor driving industry towards more benign solvents is legislation, especially Registration and Evaluation of Chemicals (REACH) in the EU which seeks to limit and eventually remove from use substances with carcinogenic, reprotoxic and mutagenic properties, as well as materials with a high environmental impact (European Chemicals Agency (ECHA), 2016). The scientific community has focused research to find greener solvents for bioprocesses and these efforts are centered on the application of ionic liquids, deep eutectic solvents and supercritical carbon dioxide (Jessop, 2011). Ionic liquids have been extensively studied by the scientific community as possible reaction media for biocatalysis. Ionic liquids are mixtures of cations and anions which do not pack well and therefore, these mixtures are in liquid phase at room temperature. Several enzymes have been tested having ionic liquids or a mixture of ionic liquid and water as reaction media. From the scientific literature, it is possible to conclude that in ionic liquids 
several enzymes present good stereoselectivity, reaction yield, activity and stability (Lou et al., 2005; Lozano et al., 2001). For example, Lozano and coworkers have studied $\alpha$-chymotrypsin and verified an increase of its half-life and the conversion of the substrate when compared to 1-propanol (Lozano et al., 2001). The implementation of ionic liquids in industrial processes will require more information regarding their toxicity, ecotoxicity and their life cycle impact. Moreover the ecotoxicity of the ionic liquid seems to be related to the branching of the alkyl chain and to hydrophobicity of the cation (Docherty and Kulpa, Jr., 2005). Some of the ionic liquids have $\mathrm{EC}_{50}$ (acute toxicity value) values much lower than for example toluene, which means they are more ecotoxic. Another aspect to consider when evaluating the environmental impact of ionic liquids is the environmental impact of their synthesis. The synthesis of an ionic liquid sometimes requires the use of harmful organic solvents (Deetlefs and Seddon, 2010; Zhang et al., 2008). There have also been efforts to decrease the toxicity of ionic liquids. In fact the third generation of ionic liquids has been considered cheaper, sustainable, non-toxic and biodegradable (Domínguez de María and Maugeri, 2011; Fukaya et al., 2007).

Supercritical carbon dioxide $\left(\mathrm{scCO}_{2}\right)$ is also considered a sustainable solvent since it is nonflammable, has low toxicity, is broadly inert limiting unwanted reactions, and is present in abundance as a by-product of industrial processes like fermentation and thermal cracking. Although $\mathrm{scCO}_{2}$ presents several advantages at safety and process level, it has also some associated disadvantages. Some organic substrates have poor solubility in $\mathrm{scCO}_{2}$, requiring the use of a cosolvent. A process which uses supercritical carbon dioxide requires high pressure equipment and therefore it is necessary to consider carefully the safety aspects. Furthermore, another constraint of the application of $\mathrm{scCO}_{2}$ in a process is the cost of operation and equipment capital cost which is much higher compared to a standard organic solvent since the process has to operate at high pressure (Beckman, 2004). Concerning application in bioprocesses, studies have demonstrated that $\mathrm{scCO}_{2}$ can improve reaction rates and control reaction selectivity by pressure. Many enzymes have been demonstrated to have a high performance in $\mathrm{scCO}_{2}$ compared to organic solvents. Examples include hydrolases, oxygenases and dehydrogenases, and have been reviewed by Wimmer and Zarevúcka, 2010. In addition, lipases seem to have been extensively studied and reported in the scientific literature (Khosravi-Darani and Mozafari, 2009). However, the enzyme is not always stable in a biphasic $\mathrm{CO}_{2} / \mathrm{H}_{2} \mathrm{O}$ system due to the dissolution of $\mathrm{CO}_{2}$ in water which causes the formation of $\mathrm{H}_{2} \mathrm{CO}_{3}$. Consequently, $\mathrm{pH}$ will decrease (2.85) and the enzyme can be deactivated. In addition, carbon dioxide is a Lewis acid and reacts with strong bases and nucleophiles (Beckman, 2004). Therefore, it is necessary to take this fact into account when considering the application of $\mathrm{scCO}_{2}$ in processes in which these compounds are substrates or products.

The solvent for a process can be chosen from several categories of solvents: water, organic solvents, ionic liquids and supercritical fluids. Jessop has consulted top academic experts in green solvents about which solvents they would choose for industrial application, and the choice fell on water, supercritical carbon dioxide and carefully-selected organic solvents (Jessop, 2011). In conclusion, the choice of a solvent for a bioprocess should comprise a balance between the effects on the environment, effects on human health, safety hazards, biocatalyst/microorganism activity, solubility and selectivity of substrates and/or products and recovery. This balance is important because it is not always possible to find a solvent which fully covers all these criteria. Problems regarding the impact of a solvent on Environment, Health and Safety are increasingly being taken into account in process development when considering the application of a solvent as a reaction medium or as part of downstream processing in new processes. Moreover, in recent years, there has been more focus to substitute the hazardous solvents in already running processes. 


\section{Acknowledgment}

This work was supported by the European Commission's Seventh Framework Programme (FP7/2007-2013) Project BIOINTENSE - Mastering Bioprocess integration and intensification across scales (Grant Agreement number 312148).

Charnwood Technical Consulting Ltd. and GlaxoSmithKline Medicines Research Centre acknowledge funding from the European Commission's Seventh Framework Programme (FP7/2007-2013) and EFPIA companies' in kind contribution for the Innovative Medicine Initiative under Grant Agreement No. 115360 (Chemical manufacturing methods for the $21^{\text {st }}$ century pharmaceutical industries, CHEM21).

\section{References}

Abildskov, J., Gani, R., Rasmussen, P., O’Connell, J.., 2001. Analysis of infinite dilution activity coefficients of solutes in hydrocarbons from UNIFAC. Fluid Phase Equilib. 181, 163-186.

Adams, D.J., Dyson, P.J., Tavener, S.J., 2003. Chemistry in alternative reaction media. John Wiley \& Sons, Ltd, Chichester.

Alder, C.M., Hayler, J.D., Henderson, R.K., Redman, A.M., Shukla, L., Shuster, L.E., Sneddon, H.F., 2016. Updating and further expanding GSK's solvent sustainability guide. Green Chem. 18, 3879-3890.

Alfonsi, K., Colberg, J., Dunn, P.J., Fevig, T., Jennings, S., Johnson, T.A., Kleine, H.P., Knight, C., Nagy, M.A., Perry, D.A., Stefaniak, M., 2008. Green chemistry tools to influence a medicinal chemistry and research chemistry based organisation. Green Chem. 10, 31-36.

American Chemical Society (ACS), 2011. ACS GCI Pharmaceutical Roundtable Solvent Selection Guide [WWW Document]. URL http://www.acs.org/content/dam/acsorg/greenchemistry/industriainnovation/roundtable/acs-gci-prsolvent-selection-guide.pdf (accessed 5.24.16).

Aono, R., Doukyo, N., Kobayashi, H., Horikoshi, K., Nakajima, H., 1994. Oxidative Bioconversion of Cholesterol by Pseudomonas sp. Strain ST-200 in a Water-Organic Solvent Two-Phase System. Appl. Environ. Microbiol. 60, 2518-2523.

Ashcroft, C.P., Dunn, P.J., Hayler, J.D., Wells, A.S., 2015. Survey of Solvent Usage in Papers Published in Organic Process Research \& Development 1997-2012. Org. Process Res. Dev. 19, 740-747.

Barwick, V.J., 1997. Strategies for solvent selection - a literature review. TrAC Trends Anal. Chem. 16, 293-309.

Bassetti, L., Tramper, J., 1994. Organic solvent toxicity in Morinda citrifolia cell suspensions. Enzyme Microb. Technol. 16, 642-648.

Beckman, E.J., 2004. Supercritical and near-critical CO2 in green chemical synthesis and processing. J. Supercrit. Fluids 28, 121-191.

Bemquerer, M.P., Adlercreutz, P., Tominaga, M., 1994. Pepsin-catalyzed peptide synthesis in organic media: studies with free and immobilized enzyme. Int. J. Pept. Protein Res. 44, 448-456. 
Bennett, C., Dordick, J.S., Hacking, A.J., Cheetham, P.S., 1992. Biocatalytic synthesis of disaccharide high-intensity sweeterner sucralose via a tetrachlororaffinose intermediate. Biotechnol. Bioeng. 39, 211-217.

Bes, M.T., Gomez-Moreno, C., Guisan, J.M., Fernandez-Lafuente, R., 1995. Selective oxidation: stabilisation by multipoint attachment of ferredoxin NADP+ reductase, an interesting cofactor recycling enzyme. J. Mol. Catal. A Chem. 98, 161-169.

Boghigian, B.A., Myint, M., Wu, J., Pfeifer, B.A., 2011. Simultaneous production and partitioning of heterologous polyketide and isoprenoid natural products in an Escherichia coli two-phase bioprocess. J. Ind. Microbiol. Biotechnol. 38, 1809-1820.

Bose, A., Keharia, H., 2013. Production, characterization and applications of organic solvent tolerant lipase by Pseudomonas aeruginosa AAU2. Biocatal. Agric. Biotechnol. 2, 255-266.

Brena, B., González-Pombo, P., Batista-Viera, F., 2013. Immobilization of enzymes: a literature survey. Methods Mol. Biol. 1051, 15-31.

Brennan, T.C.R., Turner, C.D., Krömer, J.O., Nielsen, L.K., 2012. Alleviating monoterpene toxicity using a two-phase extractive fermentation for the bioproduction of jet fuel mixtures in Saccharomyces cerevisiae. Biotechnol. Bioeng. 109, 2513-2522.

Bruce, L.J., Daugulis, A.J., 1991. Solvent selection-strategies for extractive biocatalysis. Biotechnol. Prog. 7, 116-124.

Buchholz, K., Kasche, V., Bornscheuer, U.T., 2012. Biocatalysts and enzyme technology. WileyVCH Verlag, Weinheim.

Cantarella, L., Alfani, F., Cantarella, M., 1993. Stability and activity of immobilized hydrolytic enzymes in two-liquid-phase systems: Acid phosphatase, $\beta$-glucosidase, and $\beta$-fructofuranosidase entrapped in poly(2-hydroxyethyl methacrylate) matrices. Enzyme Microb. Technol. 15, 861-867.

Carstensen, F., Apel, A., Wessling, M., 2012. In situ product recovery: Submerged membranes vs. external loop membranes. J. Memb. Sci. 394, 1-36.

Carvalho, A.C.L. de M., Fonseca, T. de S., Mattos, M.C. de, Oliveira, M. da C.F. de, Lemos, T.L.G. de, Molinari, F., Romano, D., Serra, I., 2015. Recent advances in lipase-mediated preparation of pharmaceuticals and their intermediates. Int. J. Mol. Sci. 16, 29682-29716.

Chaplin, J.A., Budde, C.L., Khmelnitsky, Y.L., 2001. Catalysis by amine oxidases in nonaqueous media. J. Mol. Catal. B Enzym. 13, 69-75.

Cheng, H.-C., Wang, F.-S., 2010. Computer-aided biocompatible solvent design for an integrated extractive fermentation-separation process. Chem. Eng. J. 162, 809-820

Cheng, H.-C., Wang, F.-S., 2007. Trade-off optimal design of a biocompatible solvent for an extractive fermentation process. Chem. Eng. Sci. 62, 4316-4324.

Clark, J.H., Tavener, S.J., 2007. Alternative solvents: Shades of green. Org. Process Res. Dev. 11, $149-155$.

Collins, A.M., Woodley, J.M., Liddell, J.M., 1995. Determination of reactor operation for the 
microbial hydroxylation of toluene in a two-liquid phase process. J. Ind. Microbiol. 14, 382-388.

Collins, L.D., Daugulis, A.J., 1997. Biodegradation of phenol at high initial concentrations in twophase partitioning batch and fed-batch bioreactors. Biotechnol. Bioeng. 55, 155-162.

Constable, D.J.C., Jimenez-Gonzalez, C., Henderson, R.K., 2007. Perspective on solvent use in the pharmaceutical industry. Org. Process Res. Dev. 11, 133-137.

Cremonesi, P., 1975. Enzymatic preparation of 20 beta-hydroxysteroids in a two-phase system. Biotechnol. Bioeng. 17, 1101-1108.

Cremonesi, P., Carrea, G., Sportoletti, G., Antonini, E., 1973. Enzymatic dehydrogenation of steroids by $\beta$-hydroxysteroid dehydrogenase in a two-phase system. Arch. Biochem. Biophys. 159, $7-10$.

Cruz, A., Fernandes, P., Cabral, J.M.S., Pinheiro, H.M., 2001. Whole-cell bioconversion of $\beta$ sitosterol in aqueous-organic two-phase systems. J. Mol. Catal. B Enzym. 11, 579-585.

Cue, B.W., Zhang, J., 2009. Green process chemistry in the pharmaceutical industry. Green Chem. Lett. Rev. 2, 193-211.

Cull, S., Woodley, J., Lye, G., 2001. Process selection and characterisation for the biocatalytic hydration of poorly water soluble aromatic dinitriles 19, 131-154.

Dafoe, J.T., Daugulis, A.J., 2014. In situ product removal in fermentation systems: improved process performance and rational extractant selection. Biotechnol. Lett. 36, 443-460.

Dortmund Bank Data, 2018. Dortmund Data Bank [WWW Document]. URL http://www.ddbst.com/ddb.html (access 3.22.2018)

Datta, S., Christena, L.R., Rajaram, Y.R.S., 2013. Enzyme immobilization: an overview on techniques and support materials. 3 Biotech 3, 1-9.

De Gonzalo, G., Lavandera, I., Faber, K., Kroutil, W., 2007. Enzymatic reduction of ketones in "micro-aqueous" media catalyzed by ADH-A from Rhodococcus ruber. Org. Lett. 9, 2163-6.

De Wulf, O., Thonart, P., 1989. Bioconversion of vanillin to vanillyl alcohol in a two-phase reactor. Appl. Biochem. Biotechnol. 20, 165-180.

Deetlefs, M., Seddon, K.R., 2010. Assessing the greenness of some typical laboratory ionic liquid preparations. Green Chem. 12, 17-30.

Devi, N.A., Radhika, G.B., Bhargavi, R.J., 2017. Lipase catalyzed transesterification of ethyl butyrate synthesis in n-hexane - a kinetic study. J. Food Sci. Technol. 54, 2871-2877.

Docherty, K.M., Kulpa, Jr., C.F., 2005. Toxicity and antimicrobial activity of imidazolium and pyridinium ionic liquids. Green Chem. 7, 185-189.

Domańska, U., Okuniewski, M., Okuniewska, P., Paduszyński, K., Turowski, T., 2015. Phase equilibrium and bioproduction of the aroma compound 2-phenylethanol in a biphasic aqueous system. Eur. Food Res. Technol. 240, 1177-1186.

Domínguez de María, P., Maugeri, Z., 2011. Ionic liquids in biotransformations: From proof-of- 
concept to emerging deep-eutectic-solvents. Curr. Opin. Chem. Biol. 15, 220-225.

Dutta, A., 1994. Two-phase culture system for plant cells. Ann. N. Y. Acad. Sci. 745, 251-260.

Dwevedi, A., 2016. Enzyme Immobilization - Advances in Industry, Agriculture, Medicine, and the Environment. Springer International Publishing, Cham.

Elgue, S., Prat, L., Cabassud, M., Cezerac, J., 2006. Optimisation of solvent replacement procedures according to economic and environmental criteria. Chem. Eng. J. 117, 169-177.

Ellegaard, M.E., Abildskov, J., O’Connell, J.P., 2009. Method for predicting solubilities of solids in mixed solvents. AIChE J. 55, 1256-1264.

Environmental Health Analysis Center, 2012. Persistent, Bioaccumulative, and Toxic (PBT) profiler [WWW Document]. URL http://www.pbtprofiler.net/ (accessed 12.1.16).

EPA (U.S. Environmental Protection Agency), 2012. Estimating Persistence, Bioaccumulation, and Toxicity Using the PBT Profiler, in: Sustainable Futures / P2 Framework Manual 2012 EPA-748B12-001. U.S. Environmental Protection Agency Office of Chemical Safety and Pollution Prevention.

European Chemicals Agency (ECHA), 2016. Registration, Evaluation, Authorisation and Restriction of Chemicals (REACH) [WWW Document]. URL http://echa.europa.eu/regulations/reach (accessed 2.9.16).

Ferrante, A.A., Augliera, J., Lewis, K., Klibanov, A.M., 1995. Cloning of an organic solventresistance gene in Escherichia coli: the unexpected role of alkylhydroperoxide reductase. Proc. Natl. Acad. Sci. 92, 7617-7621.

Fragnelli, M.C., Hoyos, P., Romano, D., Gandolfi, R., Alcántara, A.R., Molinari, F., 2012. Enantioselective reduction and deracemisation using the non-conventional yeast Pichia glucozyma in water/organic solvent biphasic systems: preparation of (S)-1,2-diaryl-2-hydroxyethanones (benzoins). Tetrahedron 68, 523-528.

Freeman, A., Woodley, J.M., Lilly, M.D., 1993. In Situ Product Removal as a Tool for Bioprocessing. Nat. Biotechnol. 11, 1007-1012.

Fukaya, Y., Iizuka, Y., Sekikawa, K., Ohno, H., 2007. Bio ionic liquids: room temperature ionic liquids composed wholly of biomaterials. Green Chem. 9, 1155-1157.

Furuhashi, K., 1986. Fermentation process for the production of optically active epoxides. CEER, Chem. Econ. Eng. Rev. 18, 21-26.

Gani, R., 2006. A modern approach to solvent selection. Chem. Eng. 113, 30-43.

Gao, Q., Demain, A., 2001. Improvement in the bioconversion of penicillin G to deacetoxycephalosporin $\mathrm{G}$ by elimination of agitation and addition of decane. Appl. Microbiol. Biotechnol. 57, 511-513.

Garikipati, S.V.B.J., McIver, A.M., Peeples, T.L., 2009. Whole-cell biocatalysis for 1-naphthol production in liquid-liquid biphasic systems. Appl. Environ. Microbiol. 75, 6545-52.

Geok, L.P., Razak, C.N.A., Abd Rahman, R.N.Z., Basri, M., Salleh, A.B., 2003. Isolation and 
screening of an extracellular organic solvent-tolerant protease producer. Biochem. Eng. J. 13, 7377.

Gonçalves, A.P.V., Lopes, J.M., Lemos, F., Ramôa Ribeiro, F., Prazeres, D.M.F., Cabral, J.M.S., Aires-Barros, M.R., 1997. Effect of the immobilization support on the hydrolytic activity of a cutinase from Fusarium solani pisi. Enzyme Microb. Technol. 20, 93-101.

Gorman, L.A., Dordick, J.S., 1992. Organic solvents strip water off enzymes. Biotechnol. Bioeng. 39, 392-397.

Gu, T., 2000. Liquid-liquid partitioning methods for bioseparations. Sep. Sci. Technol. 2, 329-364.

Hall, M., Winkler, C.K., Tasnádi, G., Faber, K., 2012. Enoate Reductases for Reduction of Electron Deficient Alkenes, in: Whittal, J., Sutton, P.W. (Eds.), Practical Methods for Biocatalysis and Biotransformation 2. John Wiley \& Sons, Ltd, Chichester.

Halling, P.J., 1994. Thermodynamic predictions for biocatalysis in nonconventional media: Theory, tests, and recommendations for experimental design and analysis. Enzyme Microb. Technol. 16, 178-206.

He, J.-Y., Sun, Z.-H., Ruan, W.-Q., Xu, Y., 2006. Biocatalytic synthesis of ethyl (S)-4-chloro-3hydroxy-butanoate in an aqueous-organic solvent biphasic system using Aureobasidium pullulans CGMCC 1244. Process Biochem. 41, 244-249.

Heipieper, H.J., Neumann, G., Cornelissen, S., Meinhardt, F., 2007. Solvent-tolerant bacteria for biotransformations in two-phase fermentation systems. Appl. Microbiol. Biotechnol. 74, 961-973.

Henderson, R.K., Jiménez-González, C., Constable, D.J.C., Alston, S.R., Inglis, G.G. a., Fisher, G., Sherwood, J., Binks, S.P., Curzons, A.D., 2011. Expanding GSK's solvent selection guide embedding sustainability into solvent selection starting at medicinal chemistry. Green Chem. 13, $854-862$.

Hocknull, M.D., Lilly, M.D., 1990. The use of free and immobilised Arthrobacter simplex in organic solvent/aqueous two-liquid-phase reactors. Appl. Microbiol. Biotechnol. 33, 148-153.

Hook, D.H., 2006. Production of antibiotics by fermentation, in: Ratledge, C., Kristiansen, B. (Eds.), Basic Biotechnology. Cambridge University Press, Cambridge.

Hua, D., Xu, P., 2011. Recent advances in biotechnological production of 2-phenylethanol. Biotechnol. Adv. 29, 654-660.

Huang, Y., Zhang, F., Gong, Y., 2005. A convenient approach to (S)-2-ethylhexan-1-ol mediated by baker's yeast. Tetrahedron Lett. 46, 7217-7219.

Hüsken, L.E., Oomes, M., Schroën, K., Tramper, J., de Bont, J.A.M., Beeftink, R., 2002. Membrane-facilitated bioproduction of 3-methylcatechol in an octanol/water two-phase system. J. Biotechnol. 96, 281-289.

Janseen, A.E.M., Van der Padt, A., Van Sonsbeek, H.M., Van't Riet, K., 1993. The effect of organic solvents on the equilibrium position of enzymatic acylglycerol synthesis. Biotechnol. Bioeng. 41, 95-103. 
Jessop, P.G., 2011. Searching for green solvents. Green Chem. 13, 1391-1398.

Jessop, P.G., Ahmadpour, F., Buczynski, M.A., Burns, T.J., Green II, N.B., Korwin, R., Long, D., Massad, S.K., Manley, J.B., Omidbakhsh, N., Pearl, R., Pereira, S., Predale, R.A., Sliva, P.G., VanderBilt, H., Weller, S., Wolf, M.H., 2015. Opportunities for greener alternatives in chemical formulations. Green Chem. 17, 2664-2678.

Jung, D.-H., Choi, W., Choi, K.-Y., Jung, E., Yun, H., Kazlauskas, R.J., Kim, B.-G., 2013. Bioconversion of p-coumaric acid to p-hydroxystyrene using phenolic acid decarboxylase from B. amyloliquefaciens in biphasic reaction system. Appl. Microbiol. Biotechnol. 97, 1501-1511.

Kamal, M.Z., Yedavalli, P., Deshmukh, M. V., Rao, N.M., 2013. Lipase in aqueous-polar organic solvents: Activity, structure, and stability. Protein Sci. 22, 904-915.

Kemeling, G.M., 2012. Editorial: Solvent Choices and Sustainable Chemistry. ChemSusChem 5, 2291-2292.

Kermasha, S., Dioum, N., Bisakowski, B., Vega, M., 2002. Biocatalysis by immobilized lipoxygenase in a ternary micellar system. J. Mol. Catal. B Enzym. 20, 305-317.

Khosravi-Darani, K., Mozafari, M.R., 2009. Supercritical fluids technology in bioprocess industries: A review. J. Biochem. Technol. 2, 144-152.

Koch, J., 2015. Design Principles for Liquid-Liquid Extraction. Chem. Eng. Prog. 111, 22-30.

Kohlmann, C., Robertz, N., Leuchs, S., Greiner, L., Na'amnieh, S., 2011. Utilising hardly-water soluble substrates as a second phase enables the straightforward synthesis of chiral alcohols. Green Chem. 13, 3093-3095.

Koláŕ, P., Shen, J.-W., Tsuboi, A., Ishikawa, T., 2002. Solvent selection for pharmaceuticals. Fluid Phase Equilib. 194, 771-782.

Kourkoutas, Y., Bekatorou, A., Banat, I.., Marchant, R., Koutinas, A.., 2004. Immobilization technologies and support materials suitable in alcohol beverages production: a review. Food Microbiol. 21, 377-397.

Koutinas, M., Yiangou, C., Osório, N.M., Ioannou, K., Canet, A., Valero, F., Ferreira-Dias, S., 2018. Application of commercial and non-commercial immobilized lipases for biocatalytic production of ethyl lactate in organic solvents. Bioresour. Technol. 247, 496-503.

Kuhn, D., Julsing, M.K., Heinzle, E., Bühler, B., 2012. Systematic optimization of a biocatalytic two-liquid phase oxyfunctionalization process guided by ecological and economic assessment. Green Chem. 14, 645-653.

Kurzrock T., Weuster-Botz D., 2010. Recovery of succinic acid from fermentation broth, Biotechnol. Lett., 32, 331-339.

Laane, C., Boeren, S., Hilhorst, R., Veeger, C., 1986. Optimization of biocatalysis in organic media, in: Laane, C., Tramper, J., Lilly, M.D. (Eds.), Biocatalysis in Organic Media. Elsevier Science Publishers B.V., Amsterdam, 65-84.

Laane, C., Boeren, S., Vos, K., Veeger, C., 1987. Rules for optimization of biocatalysis in organic 
solvents. Biotechnol. Bioeng. 30, 81-87.

Lara, P.V., Park, E.Y., 2004. Potential application of waste activated bleaching earth on the production of fatty acid alkyl esters using Candida cylindracea lipase in organic solvent system. Enzyme Microb. Technol. 34, 270-277.

Lee, Y., 1997. Whole-cell biotransformation in a biphasic aqueous-organic solutions. Preparation of optically active cis-1,3-dibenzyl-2-oxoimidazolidinedicarboxylic acid monoester as a chiral precursor of (+)-biotin. Bull. Korean Chem. Soc. 18, 101-102.

León, R., Fernandes, P., Pinheiro, H.M., Cabral, J.M.S., 1998. Whole-cell biocatalysis in organic media. Enzyme Microb. Technol. 23, 483-500.

Lima-Ramos, J., Tufvesson, P., Woodley, J.M., 2014. Application of environmental and economic metrics to guide the development of biocatalytic processes. Green Process. Synth. 3, 195-213.

Liu, W.-H., Horng, W.-C., Tsai, M.-S., 1996. Bioconversion of cholesterol to cholest-4-en-3-one in aqueous/organic solvent two-phase reactors. Enzyme Microb. Technol. 18, 184-189.

Lou, W.Y., Xu, R., Zong, M.H., 2005. Hydroxynitrile lyase catalysis in ionic liquid-containing systems. Biotechnol. Lett. 27, 1387-1390.

Lozano, P., de Diego, T., Guegan, J.P., Vaultier, M., Iborra, J.L., 2001. Stabilization of alphachymotrypsin by ionic liquids in transesterification reactions. Biotechnol. Bioeng. 75, 563-569.

Lu, J., Lazzaroni, J., Hallet, J.P., Bommarius, A.S., Liotta, C.L., Eckert, C.A., 2004. Tunable solvents for homogeneous catalyst recycle. Ind. Eng. Chem. Res. 43, 1586-1590.

Lye, G.J., Woodley, J.M., 1999. Application of in situ product-removal techniques to biocatalytic processes. Trends Biotechnol. 17, 395-402.

Mahfud F. H. ,van Geel F. P.,Venderbosch R. H., Heeres H. J., 2008. Acetic Acid Recovery from Fast Pyrolysis Oil. An Exploratory Study on Liquid-Liquid Reactive Extraction using Aliphatic Tertiary Amines, Sep. Sci. Technol., 43, 3056-3074

Malinowski, J.J., 2001. Two-phase partitioning bioreactors in fermentation technology. Biotechnol. Adv. 19, 525-538.

Malinowski, J.J., 1999. Evaluation of liquid extraction potentials for downstream separation of 1,3propanediol. Biotechnol. Tech. 13, 127-130.

Malinowski, J.J., Daugulis, A.J., 1994. Salt effects in extraction of ethanol, 1-butanol and acetone from aqueous solutions. AIChE J. 40, 1459-1465.

Marti, M.E., Gurkan, T., Doraiswamy, L.K., 2011. Equilibrium and Kinetic Studies on Reactive Extraction of Pyruvic Acid with Trioctylamine in 1-Octanol. Ind. Eng. Chem. Res. 50, 1351813525.

Martínez-Aragón, M., Burghoff, S., Goetheer, E.L.V., de Haan, A.B., 2009. Guidelines for solvent selection for carrier mediated extraction of proteins. Sep. Purif. Technol. 65, 65-72.

Meadows, R.E., Mulholland, K.R., Schürmann, M., Golden, M., Kierkels, H., Meulenbroeks, E., Mink, D., May, O., Squire, C., Straatman, H., Wells, A.S., 2013. Efficient Synthesis of ( S )-1-(5- 
Fluoropyrimidin-2-yl)ethylamine Using an $\omega$-Transaminase Biocatalyst in a Two-Phase System. Org. Process Res. Dev. 17, 1117-1122.

Meyer, D., Bühler, B., Schmid, A., 2006. Process and catalyst design objectives for specific redox biocatalysis. Adv. Appl. Microbiol. 59, 53-91.

Meyer, H.-P., Eichhorn, E., Hanlon, S., Lütz, S., Schürmann, M., Wohlgemuth, R., Coppolecchia, R., 2013. The use of enzymes in organic synthesis and the life sciences: perspectives from the Swiss Industrial Biocatalysis Consortium (SIBC). Catal. Sci. Technol. 3, 29-40.

Mionetto, N., Marty, J.L., Karube, I., 1994. Acetylcholinesterase in organic solvents for the detection of pesticides: Biosensor application. Biosens. Bioelectron. 9, 463-470.

Modarresi, H., Conte, E., Abildskov, J., Gani, R., Crafts, P., 2008. Model-Based Calculation of Solid Solubility for Solvent Selection - a Review. Ind. Eng. Chem. Res. 47, 5234-5242.

Mukhopadhyay, A., 2015. Tolerance engineering in bacteria for the production of advanced biofuels and chemicals. Trends Microbiol. 23, 498-508.

Mutti, F.G., Kroutil, W., 2012. Asymmetric Bio-amination of Ketones in Organic Solvents. Adv. Synth. Catal. 354, 3409-3413.

Najafpour, G., 2007. Production of antibiotics, in: Biochemical Engineering and Biotechnology. Elsevier B. V., Amsterdam.

Neumann, G., Kabelitz, N., Zehnsdorf, A., Miltner, A., Lippold, H., Meyer, D., Schmid, A., Heipieper, H.J., 2005. Prediction of the Adaptability of Pseudomonas putida DOT-T1E to a Second Phase of a Solvent for Economically Sound Two-Phase Biotransformations. Appl. Environ. Microbiol. 71, 6606-6612.

Norin, M., Boutelje, J., Holmberg, E., Hult, K., 1988. Lipase immobilized by adsorption. Appl. Microbiol. Biotechnol. 28, 527-530.

Oda, S., Kato, A., Matsudomi, N., Ohta, H., 1996. Enantioselective oxidation of racemic citronellol with an interface bioreactor. Biosci. Biotechnol. Biochem. 60, 83-87.

Ogawa, J., Soong, C.-L., Ito, M., Segawa, T., Prana, T., Prana, M.S., Shimizu, S., 2000. 3Carbamoyl- $\alpha$-picolinic acid production by imidase-catalyzed regioselective hydrolysis of 2,3pyridinedicarboximide in a water-organic solvent, two-phase system. Appl. Microbiol. Biotechnol. 54, 331-334.

Ogino, H., Yasui, K., Ishikawa, H., 1995. Organic solvent-tolerant bacterium which secretes an organic solvent-stable proteolytic enzyme. Appl. Environ. Microbiol. 61, 4258-4262.

Paggiola, G., Hunt, A.J., McElroy, C.R., Sherwood, J., Clark, J.H., 2014. Biocatalysis in bioderived solvents: an improved approach for medium optimisation. Green Chem. 16, 2107-2110.

Park, J.-B., Bühler, B., Panke, S., Witholt, B., Schmid, A., 2007. Carbon metabolism and product inhibition determine the epoxidation efficiency of solvent-tolerant Pseudomonas sp. strain VLB120DeltaC. Biotechnol. Bioeng. 98, 1219-1229.

Pathan, N.B., Rahatgaonkar, R.M., Chorghade, M.S., 2012. Stereoselective bioreduction of 
chalcone and beta-diketone by Saccharomyces cerevisiae in biphasic solvent system: A mechanistic study. Indian J. Chem. Sect. B-organic Chem. Incl. Med. Chem. 51, 992-1001.

Perez-Rodriguez, C., Montano, N., Gonzalez, K., Griebenow, K., 2003. Stabilization of alphachymotrypsin at the $\mathrm{CH} 2 \mathrm{Cl} 2$ /water interface and upon water-in-oil-in-water encapsulation in PLGA microspheres. J. Control. Release 89, 71-85.

Phillips, T., Chase, M., Wagner, S., Renzi, C., Powell, M., DeAngelo, J., Michels, P., 2013. Use of in situ solid-phase adsorption in microbial natural product fermentation development. J. Ind. Microbiol. Biotechnol. 40, 411-425.

Pinheiro, H.M., Cabral, J.M., 1992. Activity and stability of an entrapped-cell system for the Delta(1)-dehydrogenation of steroids in organic media. Biotechnol. Bioeng. 40, 1123-1127.

Poposka, F.A., Nikolovski, K., Tomovska, R., 1998. Kinetics, mechanism and mathematical modelling of extraction of citric acid with isodecanol/n-paraffins solutions of trioctylamine. Chem. Eng. Sci. 53, 3227-3237.

Prat, D., Hayler, J., Wells, A., 2014. A Survey of Solvent Selection Guides. Green Chem. 16, 45464551.

Prat, D., Pardigon, O., Flemming, H.-W., Letestu, S., Ducandas, V., Isnard, P., Guntrum, E., Senac, T., Ruisseau, S., Cruciani, P., Hosek, P., 2013. Sanofi's Solvent Selection Guide: A Step Toward More Sustainable Processes. Org. Process Res. Dev. 17, 1517-1525.

Prat, D., Wells, A., Hayler, J., Sneddon, H., McElroy, C.R., Abou-Shehada, S., Dunn, P.J., 2016. CHEM21 selection guide of classical- and less classical-solvents. Green Chem. 18, 288-296.

Priebe, X., Daugulis, A.J., 2018. Thermodynamic affinity-based considerations for the rational selection of biphasic systems for microbial flavor and fragrance production. J. Chem. Technol. Biotechnol. 93, 656-666.

Reslow, M., Adlercreutz, P., Mattiasson, B., 1987. Organic-solvents for bioorganic synthesis 1. Optimization of parameters for a chymotrypsin catalyzed process. Appl. Microbiol. Biotechnol. 26, $1-8$.

Rojas, A., Duque, E., Schmid, A., Hurtado, A., Ramos, J.-L., Segura, A., 2004. Biotransformation in double-phase systems: physiological responses of Pseudomonas putida DOT-T1E to a double phase made of aliphatic alcohols and biosynthesis of substituted catechols. Appl. Environ. Microbiol. 70, 3637-3643.

Rosche, B., Breuer, M., Hauer, B., Rogers, P.L., 2004. Biphasic aqueous/organic biotransformation of acetaldehyde and benzaldehyde by Zymomonas mobilis pyruvate decarboxylase. Biotechnol. Bioeng. 86, 788-794.

Savithiry, N., Cheong, T.K., Oriel, P., 1997. Production of $\alpha$-terpineol from Escherichia coli cells expressing thermostable limonene hydratase. Appl. Biochem. Biotechnol. 63, 213-220.

Schrewe, M., Julsing, M.K., Lange, K., Czarnotta, E., Schmid, A., Bühler, B., 2014. Reaction and catalyst engineering to exploit kinetically controlled whole-cell multistep biocatalysis for terminal FAME oxyfunctionalization. Biotechnol. Bioeng. 111, 1820-1830. 
Scilipoti, J.A., Cismondi, M., Andreatta, A.E., Brignole, E.A., 2014. Selection of Solvents with AUNIFAC Applied to Detoxification of Aqueous Solutions. Ind. Eng. Chem. Res. 53, 17051-17058.

Shanmuganathan, S., Natalia, D., van der Wittenboer, A., Kohlmann, C., Greiner, L., Dominguez de Maria, P., 2011. Enzyme-Catalyzed C-C Bond Formation Using 2-Methyltetrahydrofuran (2MTHF) as (Co)solvent: Efficient and Bio-Based Alternative to DMSO and MTBE. ChemInform $42,2240-2245$.

Sheldon, R.A., 2017. The E factor 25 years on: the rise of green chemistry and sustainability. Green Chem. 19, 18-43.

Sheldon, R.A., Pereira, P.C., 2017. Biocatalysis engineering: the big picture. Chem. Soc. Rev. 46, 2678-2691.

Sheldon, R.A., Woodley, J.M., 2017. Role of Biocatalysis in Sustainable Chemistry. Chem. Rev. $118,801-838$

Shi, Y.-G., Fang, Y., Wu, H.-P., Li, F., 2008. Asymmetric reduction of ethyl 2-oxo-4phenylbutyrate with baker's yeast in water/organic biphasic system. J. Biotechnol. 35, 1419-1424.

Silva, V.D., Stambuk, B.U., Nascimento, M. da G., 2010. Efficient chemoselective biohydrogenation of 1,3-diaryl-2-propen-1-ones catalyzed by Saccharomyces cerevisiae yeasts in biphasic system. J. Mol. Catal. B Enzym. 63, 157-163.

Smallwood, I.M., 1996. Handbook of organic solvent properties. John Wiley \& Sons Inc., New York.

Soo, E.L., Salleh, A.B., Basri, M., Rahman, R.N.Z., Kamaruddin, K., 2003. Optimization of the Enzyme-Catalyzed Synthesis of Amino Acid-Based Surfactants from Palm Oil Fractions. J. Biosci. Bioeng. 95, 361-367.

Stark, D., von Stockar, U., 2003. In situ product removal (ISPR) in whole cell biotechnology during the last twenty years. Adv. Biochem. Eng. Biotechnol. 80, 149-175.

Stepankova, V., Bidmanova, S., Koudelakova, T., Prokop, Z., Chaloupkova, R., Damborsky, J., 2013. Strategies for Stabilization of Enzymes in Organic Solvents. ACS Catal. 3, 2823-2836.

Straathof, A.J.J., 2003. Auxiliary phase guidelines for microbial biotransformations of toxic substrate into toxic product. Biotechnol. Prog. 19, 755-762.

Stratakos, A.C., Koidis, A., 2016. Methods for Extracting Essential Oils, in: Essential Oils in Food Preservation, Flavor and Safety. Academic Press, pp. 31-38.

Taher, H., Al-Zuhair, S., 2017. The use of alternative solvents in enzymatic biodiesel production: a review. Biofuels, Bioprod. Biorefining 11, 168-194.

Tan, Q., Day, D.F., 1998. Organic co-solvent effects on the bioconversion of (R)-(+)-limonene to (R)-(+)- $\alpha$-terpineol. Process Biochem. 33, 755-761.

Toda, H., Imae, R., Itoh, N., 2012. Efficient biocatalysis for the production of enantiopure (S)epoxides using a styrene monooxygenase (SMO) and Leifsonia alcohol dehydrogenase (LSADH) system. Tetrahedron: Asymmetry 23, 1542-1549. 
Tucker, J.L., Faul, M. M., 2016. Industrial research: Drug companies must adopt green chemistry. Nature 534, 27-29.

Tzia, C., Liadakis, G., 2003. Extraction optimization in food engineering. Marcel Dekker, Inc., New York.

Valivety, R.H., Johnston, G.A., Suckling, C.J., Halling, P.J., 1991. Solvent effects on biocatalysis in organic-systems - equilibrium position and rates of lipase catalyzed esterification. Biotechnol. Bioeng. 38, 1137-1143.

Van Hecke, W., Kaur, G., De Wever, H., 2014. Advances in in-situ product recovery (ISPR) in whole cell biotechnology during the last decade. Biotechnol. Adv. 32, 1245-1255.

Volmer, J., Neumann, C., Bühler, B., Schmid, A., 2014. Engineering of Pseudomonas taiwanensis VLB120 for constitutive solvent tolerance and increased specific styrene epoxidation activity. Appl. Environ. Microbiol. 80, 6539-6548.

Wasewar, K.L., Heesink, A.B.M., Versteeg, G.F., Pangarkar, V.G., 2002. Equilibria and kinetics for reactive extraction of lactic acid using Alamine 336 in decanol. J. Chem. Technol. Biotechnol. 77, $1068-1075$.

Wasewar, K.L., Pangarkar, V.G., Heesink, A.B.M., Versteeg, G.F., 2003. Intensification of enzymatic conversion of glucose to lactic acid by reactive extraction. Chem. Eng. Sci. 58, 33853393.

Wells, A., 2010. Biocatalytic Routes to the GPIIb/IIIa Antagonist Lotrafiban, SB 214857, in: Blaser, H.-U., Federsel, H.-J. (Eds.), Asymmetric Catalysis on Industrial Scale: Challenges, Approaches and Solutions. Wiley-VCH Verlag GmbH \& Co. KGaA, Weinheim.

Wennersten, R., 2004. Extraction of organic compounds, in: Rydberg, J., Cox, M., Musikas, C., Choppin, G.P. (Eds.), Solvent Extraction Principles and Practice. Marcel Dekker, Inc., New York.

Wiedner, R., Kothbauer, B., Pavkov-Keller, T., Gruber-Khadjawi, M., Gruber, K., Schwab, H., Steiner, K., 2015. Improving the Properties of Bacterial R-Selective Hydroxynitrile Lyases for Industrial Applications. ChemCatChem 7, 325-332.

Wimmer, Z., Zarevúcka, M., 2010. A review on the effects of supercritical carbon dioxide on enzyme activity. Int. J. Mol. Sci. 11, 233-253.

Woodley, J.M., 2017. Bioprocess intensification for the effective production of chemical products. Comput. Chem. Eng. 105, 297-307.

Woodley, J.M., Bisschops, M., Straathof, A.J.J., Ottens, M., 2008. Future directions for in-situ product removal (ISPR). J. Chem. Technol. Biotechnol. 83, 121-123.

Yang, L., Dordick, J.S., Garde, S., 2004. Hydration of Enzyme in Nonaqueous Media Is Consistent with Solvent Dependence of Its Activity. Biophys. J. 87, 812-821.

Yang, S.-T., Huang, H., Tay, A., Qin, W., De Guzman, L., Nicolas, E.C.S., 2007. Extractive Fermentation for the Production of Carboxylic Acids, in: Bioprocessing for Value-Added Products from Renewable Resources. Elsevier, pp. 421-446. 
821 Ye, Q., Cao, H., Zang, G., Mi, L., Yan, M., Wang, Y., Zhang, Y., Li, X., Li, J., Xu, L., Xiong, J., 822 Ouyang, P., Ying, H., 2010. Biocatalytic synthesis of (S)-4-chloro-3-hydroxybutanoate ethyl ester 823 using a recombinant whole-cell catalyst. Appl. Microbiol. Biotechnol. 88, 1277-1285.

824 Zaks, A., 1988. The effect of water on enzyme action in organic media. J. Biol. Chem. 263, 80178258021.

826 Zaks, A., Klibanov, A. M., 1985. Enzyme-catalyzed processes in organic solvents. Proc. Natl. 827 Acad. Sci. U. S. A. 82, 3192-3196.

828 Zhang, F., Qian, X., Si, H., Xu, G., Han, R., Ni, Y., 2015. Significantly improved solvent tolerance 829 of Escherichia coli by global transcription machinery engineering. Microb. Cell Fact. 14, 175.

830 Zhang, Y., Bakshi, B.R., Demessie, E.S., 2008. Life cycle assessment of an ionic liquid versus 831 molecular solvents and their applications. Environ. Sci. Technol. 42, 1724-1730.

832 Zhou, T., Qi, Z., Sundmacher, K., 2014. Model-based method for the screening of solvents for 833 chemical reactions. Chem. Eng. Sci. 115, 177-185.

834 Zhu, S., Ma, X., Su, E., Wei, D., 2015. Efficient hydration of 2-amino-2,3-dimethylbutyronitrile to 835 2-amino-2,3-dimethylbutyramide in a biphasic system via an easily prepared whole-cell biocatalyst. 836 Green Chem. 17, 3992-3999.

837 Zou, S.-P., 2014. Enhancement of (S)-2,3-dichloro-1-propanol production by recombinant whole838 cell biocatalyst in n-heptane-aqueous biphasic system. J. Biotechnol. 188, $42-47$. 